\title{
Transforming Smallholder Agriculture to Achieve the SDGs
}

\author{
Mathew Abraham and Prabhu Pingali
}

\begin{abstract}
There is overwhelming historical evidence from the developed world and from the newly emerging economies of the developing world that indicates that agricultural growth has been the primary engine of overall economic growth. The transformation of economies around the world, from predominantly agricultural to industrial, was kick-started by rapid agricultural productivity growth. Does the growth in agricultural productivity have to necessarily come from the small farm sector? Rapid improvement in small farm productivity is one of the primary mechanisms by which dramatic rural poverty reductions can be achieved as shown by the Green Revolution experience in Asia and more recently in sub-Saharan Africa. Economic growth policies that are inclusive of smallholder farmers directly contribute to the SDG 2 that is focused on ending hunger, achieving food security and promoting sustainable agriculture. Past efforts at small farm productivity improvement were focused on staple grains, looking ahead one needs to take a food systems perspective and encourage diversification into nutrition-rich legumes, pulses, horticulture crops and livestock. Investment in rural market infrastructure allows smallholders to commercialise and enhance the supply of perishable products. Linking small farms to urban food value chains is also a promising new avenue for rural poverty reduction.
\end{abstract}

\section{Introduction}

In 2015, the United Nations approved the 2030 Agenda for Sustainable Development, setting in motion the Sustainable Development Goals (SDGs). The 17 goals of the SDGs have 169 targets, designed to take a holistic approach to addressing the social, economic and environmental aspects of sustainable development. Although

\footnotetext{
M. Abraham $(\varangle)$. P. Pingali

Tata-Cornell Institute for Agriculture and Nutrition, The Charles H. Dyson School of Applied Economics and Management, Cornell University, Ithaca, New York, USA e-mail:ma947@cornell.edu

P. Pingali

e-mail: plp39@cornell.edu

(C) The Author(s) 2020

S. Gomez y Paloma et al. (eds.), The Role of Smallholder Farms in Food and Nutrition Security, https://doi.org/10.1007/978-3-030-42148-9_9
} 
Goal 2 of the SDGs - which aims to end hunger and malnutrition and double agricultural productivity and incomes of small-scale farmers-is directly linked to small farm production, eight other goals related to ending poverty, gender discrimination, inequality and environmental degradation, tackling climate change, and promoting and ensuring healthy lives have small farm development and growth central to their success. A majority of the world's agricultural production takes place on small farms, and currently $90 \%$ of the 570 million farms globally are small (less than 2 ha in size) and cultivated by 1.5 billion of the world's poor (Rapsomanikis 2015). In Asia and sub-Saharan Africa (SSA), where the problems of hunger and poverty are most severe, $80 \%$ of food supply comes from smallholders ${ }^{1}$. Therefore, assuring the viability of small farms is crucial to meeting the SDGs.

Small farms face numerous challenges in production, especially in terms of access to essential factors of production, such as credit, inputs (seeds, fertilisers, pesticides), information and production technologies, in addition to poor access to output markets (Pingali 2012; Poulton et al. 2010). Small farms are heterogeneous economic units of agricultural production. Their characteristics and challenges vary according to geography, the influence of historical institutions and the political and socioeconomic conditions in which they are situated. Therefore, addressing the concerns of small farm productivity and designing potential solutions to address them will vary within and across countries. Improving agricultural productivity and householdlevel incomes are central to reducing the poverty and nutritional challenges we face globally.

The aim of this chapter is to identify the various challenges in small farm economies at various stages of structural transformation, and the major interventions that are needed to improve their productivity in the context of meeting the SDG of ending poverty and ensuring prosperity for all. In the first part of the chapter, we identify the various goals of the SDGs that explicitly depend on small farm growth for their achievement, bringing to light the importance and urgency of interventions in small farm production systems. Productivity in small farms is influenced by geography, sociopolitical conditions and policy, and the farms vary in economies at different levels of structural transformation. In the second part of this chapter, we look at the major characteristics of low-productivity agricultural systems (much of SSA), modernising agricultural systems (South Asia and Latin America) and commercialised agricultural systems (East Asian economies; mainly South Korea, Taiwan and Japan). Here, we try to ascertain how challenges to the development of smallholder agriculture differ in each region, to make a case for context-specific interventions to achieve the SDGs.

In the last part, using a transaction cost framework, we try to understand the major challenges small farms face in different production systems, and we explain how these challenges may hinder farm viability. We also discuss how transaction costs, at both farm level and market level, may influence the incentives and capacity of different production systems to innovate, produce and sell, which forms the basis

\footnotetext{
${ }^{1}$ http://www.fao.org/fileadmin/templates/nr/sustainability_pathways/docs/Factsheet_ SMALLHOLDERS.pdf.
} 
for the development and growth of small farms. Here, we try to assess the various policy and institutional interventions that have the potential to mitigate transaction costs, at both the production and marketing stages, in different regions. We argue that in different agricultural systems, different sets of interventions are necessary to enable small farm growth.

\section{Achieving the SDGs and the Centrality of Small Farms}

The World Food Summit (WFS) goals and the Millennium Development Goals (MDGs) framework were the first systematic global attempts to monitor progress towards hunger reduction through internationally agreed benchmarks. The WFS took place in Rome in 1996, with representatives from 182 nations pledging, '...to eradicate hunger in all countries, with an immediate view to reducing the [absolute] number of undernourished people to half their present level no later than 2015'. The number of undernourished is those who fall below the minimum level of dietary consumption for a given country and year. Five years later in 2001, the UN as part of its MDG framework established a second benchmark, by which representatives of 189 nations pledged to fight extreme poverty in its many dimensions and 'to halve, between 1990 and 2015, the proportion of people whose income is less than one dollar a day ... [and] ... the proportion of people who suffer from hunger'. This became the first of the eight MDGs. Its central aim was to halve the prevalence of undernourishment, or the proportion of people below the minimum level of dietary consumption, between 1990 and 2015 (MDG 1c).

Although the MDG target of halving the prevalence of hunger was met, the WFS goal of halving absolute numbers of hungry was not accomplished (Pingali 2016). That said, the WFS goals and the MDGs did play a crucial role in shaping global thinking and action around poverty and hunger, paving the way for a bolder set of development goals. In 2015, UN member states approved the 2030 Agenda for Sustainable Development - to be achieved through 17 SDGs-in order to 'build on the work of the MDGs and complete what they did not achieve'. ${ }^{2}$ Given that the SDGs were designed to take a holistic approach to addressing the social, economic and environmental aspects of sustainable development, that they were developed through an extensive consultative process, and that they are riding on the momentum of the MDG experience, the SDGs present a good opportunity for the world to continue the progress made in the MDG era. This is a bold vision. We believe the transformation of smallholder agriculture is critical to the task.

To summarise, Table 1 lists the 17 SDG goals and targets the global community has pledged to address by the year 2030. Out of the 17 goals, 9 goals (italics) directly pertain to the agricultural sector and have relevance to small farm growth and development.

\footnotetext{
${ }^{2}$ United Nations (2015) .
} 
Table 1 The 17 sustainable development goals

\begin{tabular}{|c|c|c|}
\hline & Goal & Target \\
\hline 1 & No poverty & End poverty in all its forms everywhere \\
\hline 2 & Zero hunger & $\begin{array}{l}\text { End hunger, achieve food security and } \\
\text { improved nutrition and promote sustainable } \\
\text { agriculture }\end{array}$ \\
\hline 3 & Good health and well-being & $\begin{array}{l}\text { Ensure healthy lives and promote well-being } \\
\text { for all at all ages }\end{array}$ \\
\hline 4 & Quality education & $\begin{array}{l}\text { Ensure inclusive and equitable quality } \\
\text { education and promote lifelong learning } \\
\text { opportunities for all }\end{array}$ \\
\hline 5 & Gender equality & $\begin{array}{l}\text { Achieve gender equality and empower all } \\
\text { women and girls }\end{array}$ \\
\hline 6 & Clean water and sanitation & $\begin{array}{l}\text { Ensure availability and sustainable } \\
\text { management of water and sanitation for all }\end{array}$ \\
\hline 7 & Affordable and clean energy & $\begin{array}{l}\text { Ensure access to affordable, reliable, } \\
\text { sustainable and modern energy for all }\end{array}$ \\
\hline 8 & Decent work and economic growth & $\begin{array}{l}\text { Promote sustained, inclusive and sustainable } \\
\text { economic growth, full and productive } \\
\text { employment and decent work for all }\end{array}$ \\
\hline 9 & Industry, innovation and infrastructure & $\begin{array}{l}\text { Build resilient infrastructure, promote } \\
\text { inclusive and sustainable industrialisation and } \\
\text { foster innovation }\end{array}$ \\
\hline 10 & Reduced inequalities & $\begin{array}{l}\text { Reduce inequality within and among } \\
\text { countries }\end{array}$ \\
\hline 11 & Sustainable cities and communities & $\begin{array}{l}\text { Make cities and human settlements inclusive, } \\
\text { safe, resilient and sustainable }\end{array}$ \\
\hline 12 & Responsible consumption and production & $\begin{array}{l}\text { Ensure sustainable consumption and } \\
\text { production patterns }\end{array}$ \\
\hline 13 & Climate action & $\begin{array}{l}\text { Take urgent action to combat climate change } \\
\text { and its impacts }\end{array}$ \\
\hline 14 & Life below water & $\begin{array}{l}\text { Conserve and sustainably use the oceans, seas } \\
\text { and marine resources for sustainable } \\
\text { development }\end{array}$ \\
\hline 15 & Life on land & $\begin{array}{l}\text { Protect, restore and promote sustainable use } \\
\text { of terrestrial ecosystems, sustainably manage } \\
\text { forests, combat desertification, and halt and } \\
\text { reverse land degradation and halt } \\
\text { biodiversity loss }\end{array}$ \\
\hline 16 & Peace, justice and strong institutions & $\begin{array}{l}\text { Promote peaceful and inclusive societies for } \\
\text { sustainable development, provide access to } \\
\text { justice for all and build effective, accountable } \\
\text { and inclusive institutions at all levels }\end{array}$ \\
\hline 17 & Partnership for the goals & $\begin{array}{l}\text { Strengthen the means of implementation and } \\
\text { revitalise the global partnership for } \\
\text { sustainable development }\end{array}$ \\
\hline
\end{tabular}

Source https://sustainabledevelopment.un.org/sdgs 
Small producer agriculture

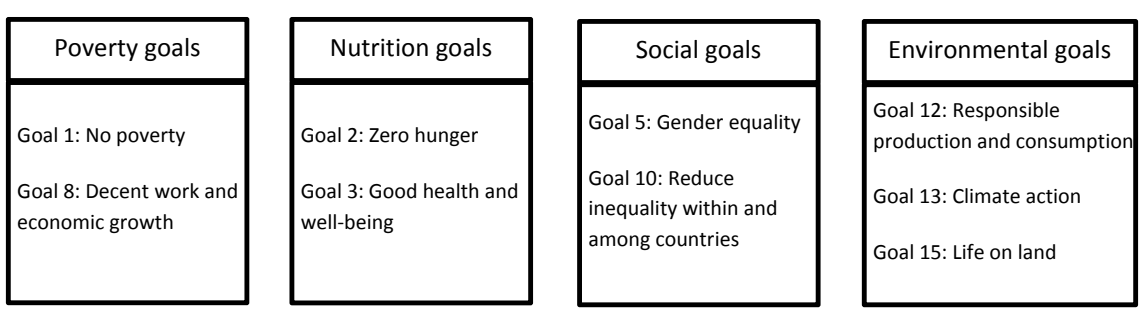

Fig. 1 Various goals for small producer agriculture development and growth

With over 1.5 billion people living in small producer households globally, their development is crucial for income growth, poverty reduction, food security, gender empowerment and environmental sustainability (Byerlee et al. 2009; Pingali 2010). Therefore, the growth and development of small producer agriculture are central to meeting the SDGs. In developing countries, multiple stressors (climatic as well as political), economic and social conditions influence food security (Leichenko and O'Brien 2002). In order to contextualise the SDGs and small farm development, we categorise SDGs into poverty, nutritional, social and environmental goals (Fig. 1). In the following subsections, we look at each of these goals in the context of small farm development and growth, to assess the major challenges in achieving them.

\subsection{Poverty Goals}

The SDG to end poverty in all its forms everywhere is especially targeted at over 836 million people who live on less than USD 1.25 a day. With a majority of the poor engaged in the agricultural sector, its growth and development are central to achieving this goal. Access to natural resources, property rights, basic services (R\&D, finance) and risk reduction (price and climatic) become crucial for improving agricultural production. The role of agriculture development in poverty reduction is well established in economics literature. There is overwhelming evidence that, with very few exceptions, sustained reduction in poverty cannot be achieved without productivity increases in the agricultural sector (Timmer and Akkus 2008). Time series data used in various studies have shown the marginal effects of agricultural GDP growth on poverty reduction to be significant. Thirtle et al. (2003) estimated that with a $1 \%$ increase in crop productivity in Asia, poverty reduced by $0.48 \%$. In the context of India, Fan et al. (2000) show a decrease of $0.24 \%$ in poverty with $1 \%$ growth in agricultural productivity. The experience in China, where there is more equitable land distribution, shows that growth in agricultural GDP led to four times higher reduction in poverty than in the non-agricultural sector (Ravallion and Chen 2007). In low-income countries, Christiaensen et al. (2006) find a 2.3 times larger 
increase in poverty reduction with agricultural growth. The same study shows a 4.25 times larger increase in SSA and a 1.34 times larger increase in the middle-income countries of North Africa.

Thus, growth and development of the agricultural sector are central to achieving the poverty goals (SDG 1 and SDG 8). These goals are also interlinked with the other group of goals identified in Fig. 1, as improved income is crucial to improving access to nutritious food, to end hunger and to reduce inequality both within and between countries. Reducing social inequality through empowerment of women and marginalised groups expands access to resources and services, which in turn can improve farm-level productivity. The urgency of climate action and conservation is also significant and inextricably linked to agricultural production. Along with increasing and sustaining growth, ensuring responsible production and consumption is important for reducing externalities such as emissions, soil degradation, water contamination and climate change, which ultimately put agricultural production at risk.

\subsection{Nutrition Goals}

The goal to end hunger, achieve food security and improve nutritional status is urgent. According to the FAO, 795 million people globally are undernourished; a majority of them live in Asia and about 281 million reside in SSA (FAO, IFAD and WFP 2015). Micronutrient deficiencies were a major issue that was under-addressed in the MDG and WFS goals of halving the prevalence and instances of the hungry (Pingali et al. 2016). The SDGs, however, are explicit in their aim to improve nutrition and to end all forms of malnutrition, focusing especially on wasting and stunting and also on the needs of adolescent girls, pregnant and lactating women and older people ${ }^{3}$. With over 3.1 million child deaths each year due to poor nutrition, and 66 million primary school children hungry (23 million in Africa alone), this is a major challenge. Although the number of stunted children under 5 declined from 225 million to 159 million globally, Africa and Oceania saw a 23 and $67 \%$ respective increase in the number of stunted children (ibid.). In terms of women's health, maternal mortality is also a serious concern globally. World Health Organization (WHO) data show that maternal mortality is 14 times higher in developing countries, and much of it is nutrition-based and preventable. In addition, about $42 \%$ of pregnant women in developing countries are anaemic (Kraemer and Zimmermann 2007), a condition which contributes to $20 \%$ of all maternal deaths.

Smallholder agricultural production is closely linked with nutrition and food security in three ways. Firstly, it makes food available through production; secondly, it reduces the real cost of food, making it more affordable; and thirdly, it improves incomes of farming households, enabling them to access nutritious foods (Ivanic

\footnotetext{
${ }^{3}$ Sustainable Development Goals Knowledge Platform-https://sustainabledevelopment.un.org/ $\operatorname{sdg} 2$.
} 


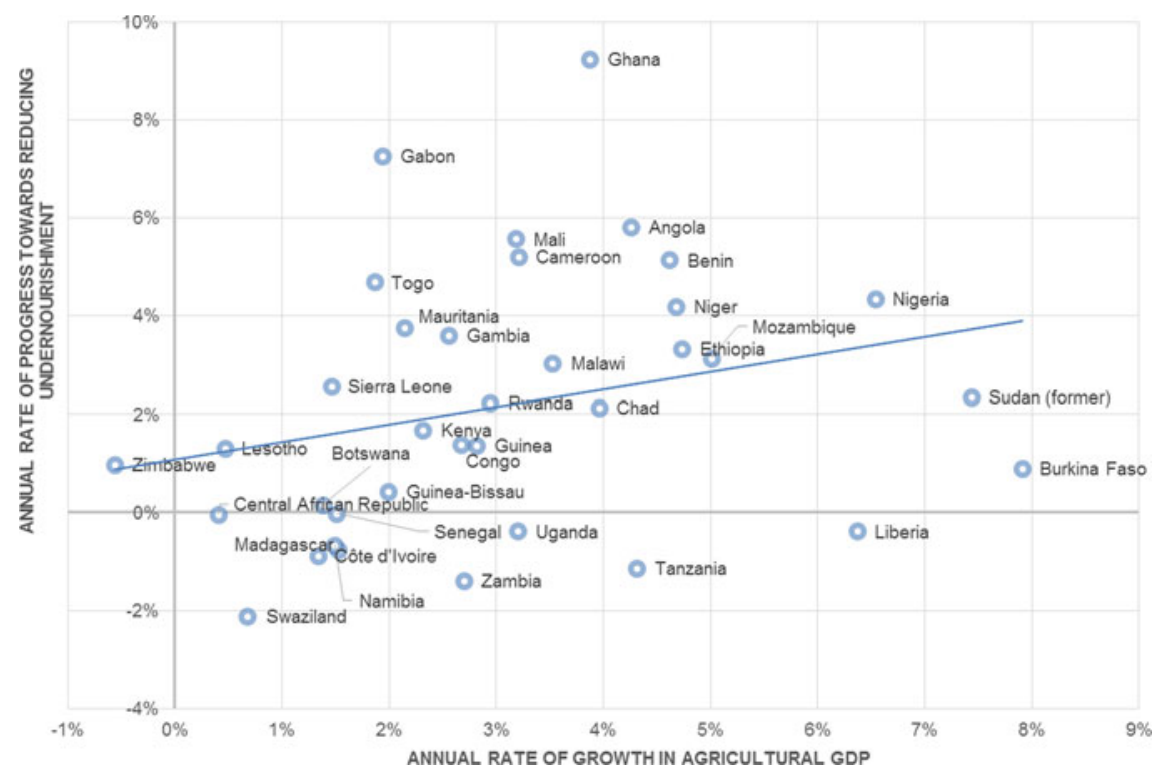

Fig. 2 Agricultural growth and reduction in hunger prevalence in SSA. Source Authors' analysis using FAO data for 2015

and Martin 2008; Pingali et al. 2015; Swinnen and Squicciarini 2012). Sufficient evidence exists to validate the relationship between agricultural growth and nutritional outcomes. Countries that proactively support pro-agricultural growth policies witnessed lower incidence of child stunting compared to countries that did not (Webb and Block 2012). FAO data substantiate this claim. For example, our analysis using FAO data shows that increases in agricultural growth correlate with decreases in hunger, stunting and child mortality in SSA (see Figs. 2, 3 and 4, respectively.) In other regions too, when there is support for sustaining agricultural development through policies targeting small producers, the resultant greater affordability of food has led to a decline in stunting and wasting. Meanwhile, countries with low agricultural productivity have consistently performed poorly on all three indicators (ibid.).

\subsection{Social Goals}

Achieving the social goal of reduced social inequality—especially gender inequality - depends on improved access to economic resources including land, natural resources, financial services and technology, for women and marginalised groups. Emancipation of these groups will be important to improve agricultural productivity, reduce regional inequalities and achieve sustained income growth. Women comprise $43 \%$ of the total agricultural labour force across the globe (FAO 2014), although 


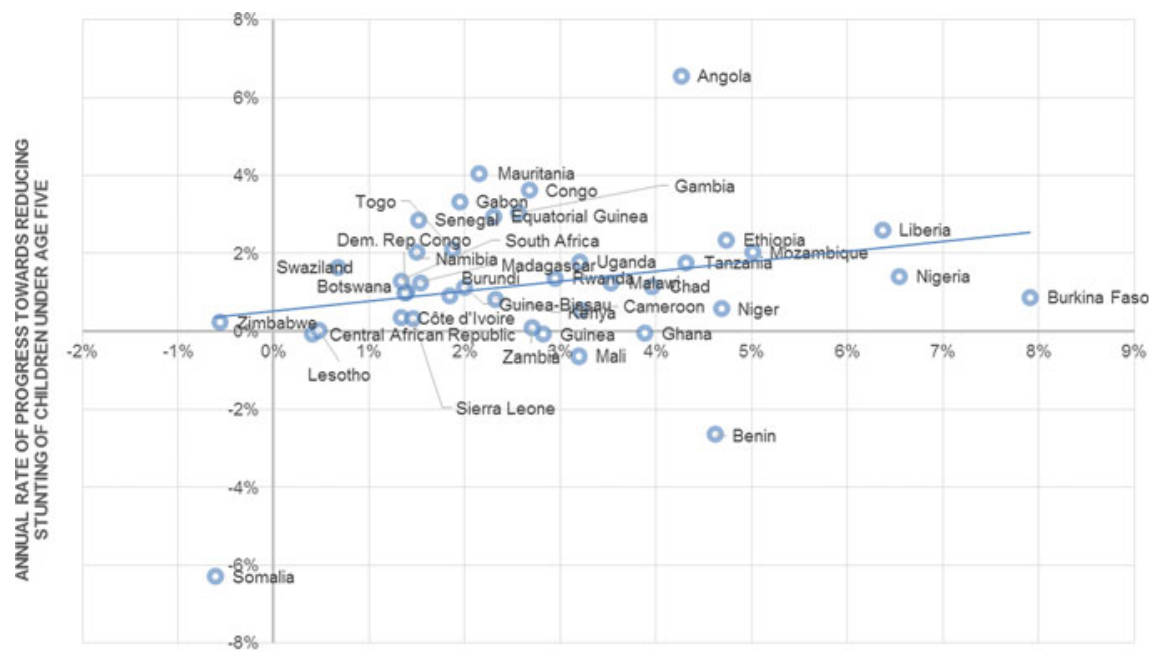

ANNUAL RATE OF GROWTH IN AGRICULTURAL GDP

Fig. 3 Agricultural growth and reduction in prevalence of child stunting in SSA. Source Authors' analysis using FAO data for 2015

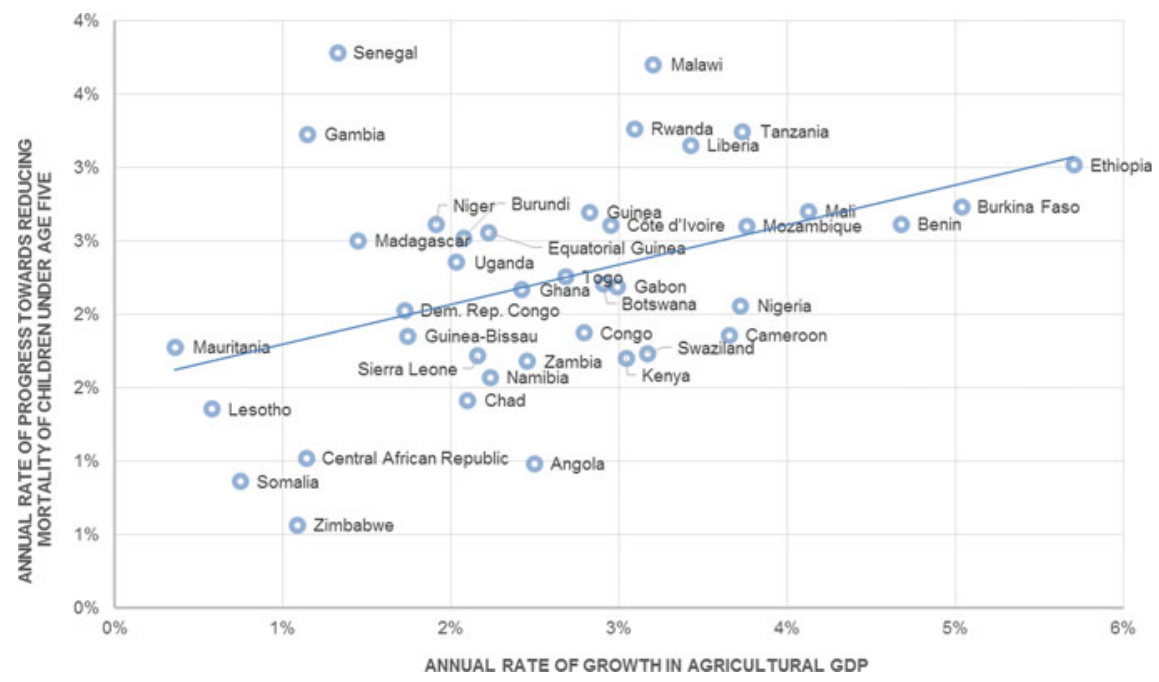

Fig. 4 Agricultural growth and reduction in prevalence of child mortality in SSA. Source Authors' analysis using FAO data for 2015

there are variations in this composition across the developing world. In SSA and in Southeast and East Asia, the percentage of women in agriculture is 50\%, while in South Asia it is 35\% and in Latin America, a little over 20\% (FAO 2011). Women also make up over $66 \%$ of the 600 million small livestock managers (Distefano 2013). 
It has been well established that there are high gender gaps, to the disadvantage of women, in access to and control of resources, especially land (Goldstein and Udry 2005; Quisumbing and Pandolfelli 2010), labour (Fontana 2009; Tzannatos 1999), credit (Sheahan and Barrett 2014), infrastructure, information and technology (Carr and Hartl 2010; Jost et al. 2016; Perez et al. 2015). This is largely due to institutional and norm-based constraints women face in society (Croppenstedt et al. 2013). The FAO (2011) reports that the underperformance of the agricultural sector is in part due to this differential access to resources for women, who represent a crucial aspect of production. Croppenstedt et al. (2013) conclude that fewer women (compared to men) are involved in the more profitable aspect of agriculture, i.e. commercial production.

\subsection{Environmental Goals}

The environmental goals, including climate action (SDG 13), responsible production and consumption (SDG 12), and the management and preservation of natural resources and biodiversity (SDG 15) are integral to small farm development. Temperature rises, and the unpredictability of floods, droughts and other extreme weather events resulting from climate change, influence the costs and conditions in which agricultural production takes place. At the same time, managing the environmental externalities of agricultural production, such as greenhouse gas (GHG) and non-GHG emissions, groundwater depletion and soil degradation, are also important concerns to increase food production for a growing population. Sustainable production and consumption therefore become an integral part of mitigation and adaptation strategies in the fight against climate change and wastage (especially for food and natural resources).

Changes in temperature increase the risks of pest attacks and disease outbreaks (O'Brien et al. 2004). This increases the cost of cultivation, due to the need for pest and disease management, and also escalates the risks of crop failure. Morton (2007) states that even a slight increase in temperature affects the conditions under which the major staples such as wheat, rice and maize are grown. Livestock production will also be impacted by climate change, posing significant and diverse challenges for food security. Quality and quantity of feed crop and forage, water availability, animal and milk production, livestock diseases and biodiversity are all important factors that will affect animal husbandry (Rojas-Downing et al. 2017). Temperature rise and humidity have an additional impact on food safety as they increase the risk of mycotoxin contamination in cereals and pulses (Paterson and Lima 2010), and of contamination of drinking water (Paerl and Huisman 2009), which in turn impacts nutrition outcomes (SDG 2 and SDG 3).

The externalities of agricultural production on the environment are also an important issue to consider in terms of climate change and of safeguarding the ecosystem. Deforestation, desertification, biodiversity loss and land degradation result from agricultural and infrastructure development. The agricultural sector accounts for $10-12 \%$ 
of global anthropogenic GHG emissions, and it is also the main source of non-carbon dioxide GHGs, such as methane $\left(\mathrm{CH}_{4}-50 \%\right)$ and nitrous oxide $\left(\mathrm{N}_{2} \mathrm{O}-60 \%\right)$ (Smith et al. 2007; Tubiello et al. 2013). The main sources of $\mathrm{CH}_{4}$ emissions are enteric fermentation in livestock, anaerobic fermentation from inundated paddy, and livestock manure management. The major sources of $\mathrm{N}_{2} \mathrm{O}$ are animal manure, synthetic fertilisers and crop residues. Myers et al. (2014) research using experimental data shows that high levels of $\mathrm{CO}_{2}$ in wheat and rice cultivation decreases the grains' micronutrients, such as zinc (by $9.3 \%$ ), iron $(5.1 \%)$ and protein $(7.8 \%$ in rice and $6.3 \%$ in wheat). Their research also shows that there was a small decrease in protein in field peas. This points to another potential impact climate change may have on nutrition (SDG 2).

Intervention and adaptation need to go together to mitigate the effects of climate change on smallholder agriculture and reduce the externalities from agricultural production. Extension services to improve agronomic practices and access to technology and infrastructure are important for smallholders to know how to adapt. Ensuring reduced wastage of food and food products, at the farm level and along the value chain, is also important to reduce production pressure and increase accessibility of food.

Overall, the growth and development of small producer agriculture systems are vital for meeting the poverty, nutrition, social and environmental goals. However, small producers are faced with significant challenges and constraints, characterised by poor access to production factors and agricultural commodity markets. High transaction costs in accessing goods and services hinder income growth and access to food, while increasing social pressures towards exploitation and drudgery to reduce labour costs. Environmental pressures, leading to land degradation and increased emissions, also result from low access to technology and poor agronomic practices that exert stresses on land to maximise returns. Understanding these challenges and constraints is crucial in enabling small farm development and growth. In the next section, we look at the specific characteristics of small farms and the major transaction costs they incur that limit their viability.

\section{Economics of Small Farms and Stages of Structural Transformation}

A majority of the world's agricultural production takes place on small and marginal farms and despite recurring predictions that small farms will soon disappear, they have persisted and in many cases have increased in number (Hazell et al. 2010). There are dramatic variations across the globe in landholding sizes and growth trends. SSA, South Asia, Southeast and East Asia largely comprise small farms with less than 2 ha of land, while in Europe and North America, landholdings are larger, averaging over 10 ha (Eastwood et al. 2010). Data from the 1970s onward show farms in North America, Europe and Oceania showing consolidating trends, while farms in Asia and 
Table 2 Trends in landholding sizes in selected countries in selected years

\begin{tabular}{l|l|l|l|l|l}
\hline Country & Period I & \multicolumn{3}{l}{ Period II } & \\
\hline Year & Farm size (ha) & Year & Farm size (ha) & $\begin{array}{l}\text { Percentage } \\
\text { change }\end{array}$ \\
\hline Canada & 1971 & 187.6 & 2011 & 315 & 68.44 \\
\hline USA & 1969 & 157.6 & 2012 & 175.6 & 5.09 \\
\hline Australia & 1970 & 1920.3 & 2001 & 3232.1 & 68.31 \\
\hline France & 1970 & 22.07 & 2010 & 54.6 & 140.6 \\
\hline Spain & 1972 & 17.83 & 2010 & 24 & 23.38 \\
\hline Japan & 1970 & 1 & 2002 & 1.57 & 57.00 \\
\hline Korea Rep. & 1970 & 0.88 & 2002 & 1.4 & 59.09 \\
\hline Peru & $1971-72$ & 16.92 & 1994 & 20.1 & 18.79 \\
\hline Brazil & 1970 & 59.4 & 1996 & 72.8 & 22.56 \\
\hline Guatemala & & & 2006 & 1.06 & \\
\hline India & $1971-72$ & 2.3 & 2011 & 1.10 & -52.17 \\
\hline China & 1980 & 0.6 & 1999 & 0.4 & -33.33 \\
\hline Indonesia & 1973 & 1.1 & 1993 & 0.9 & -18.18 \\
\hline Ethiopia & 1977 & 1.4 & $2001-02$ & 1 & -28.57 \\
\hline Kenya & & & 2005 & 0.86 & \\
\hline DRC & 1970 & 1.5 & 1990 & 0.5 & -66.67 \\
\hline Malawi & & & 2011 & 0.72 & \\
\hline Tanzania & & & 2009 & 1.5 & \\
\hline Source Com & & & & & \\
\hline
\end{tabular}

Source Compiled from FAO (http://www.fao.org/family-farming/data-sources/dataportrait/farmsize/en/); Chand et al. (2011); Fan and Chan-Kang (2005); Nagayets (2005)

Africa have been experiencing fragmentation (Table 2). In one group of countries with small or marginal landholdings (less than 1 ha), farms have become smaller (China, India, Ethiopia, DRC and Indonesia) and in the other, medium landholdings have become small (Pakistan and Philippines). India is interesting because its average landholding size witnessed one of the highest percentage decreases. In the light of these trends, it becomes more important to assess the influences of small farm viability.

Understanding the relationship between land size and productivity is important to assess the potential and challenges for small farms, and to assess the impact of decreasing landholding sizes on growth of the agricultural sector. Landholding size and productivity have been debated in studies of rural development and economics for a long time. Since the 1960s, economists have argued that crop productivity per unit of land declined with an increase in farm size (Bardhan 1973; Mazumdar 1965; Sen 1962), which has led to the emergence of the 'small farm paradigm', which states that there is an inverse relationship between farm size and productivity. These studies conclude that small farms have an advantage over large farms in per capita 
productivity, due to higher labour utilisation (e.g. using family labour) and higher input utilisation (e.g. using intensive farming practices). This inverse relationship is a result of imperfect land and labour markets (Bardhan 1973; Sen 1966). Imperfections in the labour market meant that surplus labour was available at the household level, as off-farm opportunity costs (off-farm wages minus search and travel costs) were higher than on-farm wages, and low-cost labour allows for substituting 'lumpy' inputs such as capital-intensive equipment (Binswanger and Rosenzweig 1986; Eastwood et al. 2010; Poulton et al. 2010). Imperfect land markets meant that land lease options, to access more land for farming, were limited (Eswaran and Kotwal 1986; Hazell et al. 2010) and producers have had to effectively utilise their existing resource endowment. In some regions of South and Southeast Asia, landlords became credit providers to incentivise land lease and sharecropping (Basu 1997; Otsuka et al. 1992; Srivastava 1989). Therefore, in many Asian countries (where land was scarce and labour abundant), the 'small farm paradigm' did hold. In fact, this was considered a socially optimal outcome (Hazell et al. 2010; Poulton et al. 2010).

Since fixed costs are high on small farms, it is more difficult to take advantage of the economies of scale which can be beneficial to agricultural development. In fact, some studies show that the inverse relationship between small size and high productivity disappears when taking into account soil quality (Benjamin 1995; Bhalla and Roy 1988), capital market imperfections (Feder 1985) and unobserved heterogeneities such as climatic variations and quality of management (Eastwood et al. 2010). For example, capital market imperfections limit access to credit for farms with low land endowments, because they have limited value as collateral (Besley 1995a, 1995b; Bhaduri 1977; Ghosh 2013; Ghosh et al. 2001). This in turn constrains access to inputs, extension services, technology and lumpy inputs such as management and asset-specific machinery. Due to a limited volume of production, small farms often do not have bargaining power, which often leads to poor price realisation (Hazell et al. 2010; Johnson and Ruttan 1994; Poulton et al. 2010).

The development of smallholder agriculture is central to the structural transformation process in all developing countries. Growth in agricultural productivity leads to surplus creation and increased market participation by small farms, resulting in rising household-level incomes and welfare gains. This increased engagement with markets is referred to as commercialisation (Carletto et al. 2017; Pingali and Rosegrant 1995). Commercialisation is essential for the transfer of surplus in the form of food, labour and capital from the agrarian sector to the industrial and service sectors, to enable structural transformation (Timmer 1988). Different small farmbased economies are at various stages of structural transformation; they can be categorised as low-productivity agricultural systems, modernising agricultural systems and commercialised agricultural systems (Pingali et al. 2015). Figure 5 shows the performance of selected small farm-based economies at different stages of structural transformation. Countries with low per capita incomes and larger shares of agricultural contributions to GDP are referred to as low-productivity agricultural systems. Many of the SSA countries are classified as such and in these regions, hunger and poverty remain high. 


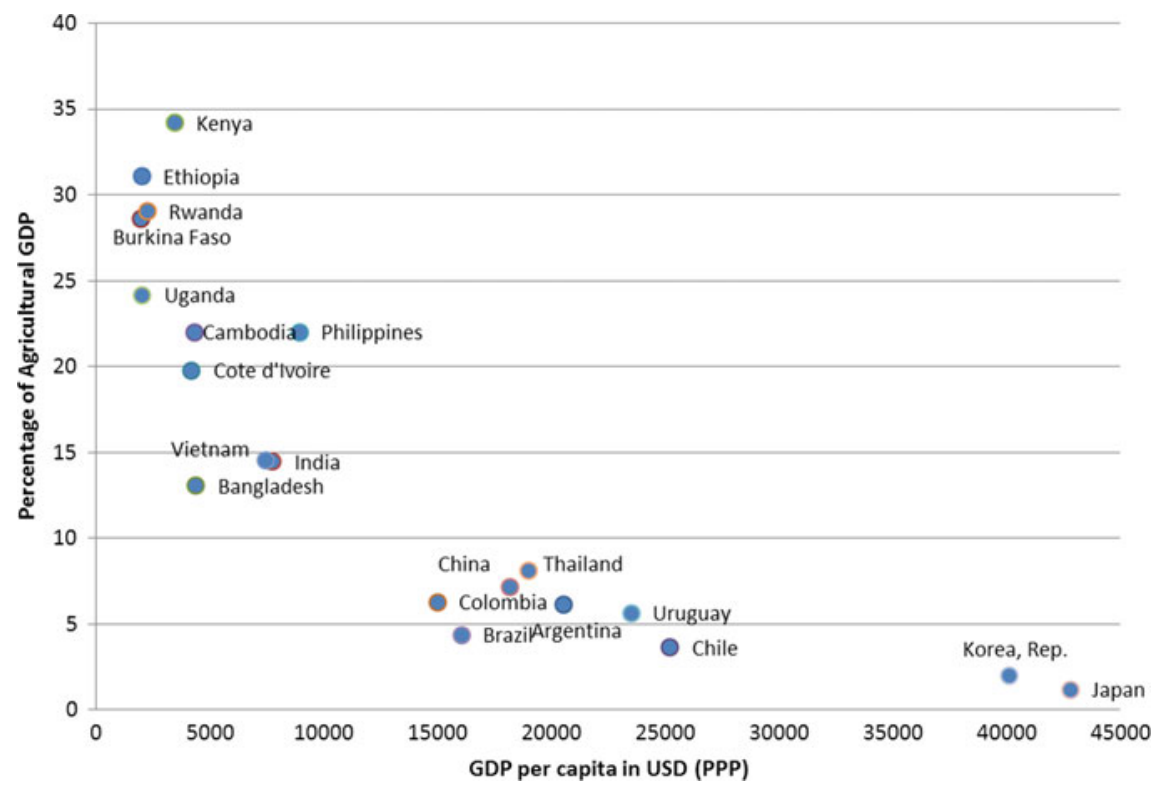

Fig. 5 Structural transformation and agricultural performance in selected countries. Source FAOSTAT and World Bank Data (2018)

Latin American, Southeast Asian and South Asian countries are classified as modernising agricultural systems, as they have medium-level per capita incomes between USD 5000 and 15,000 and their GDP contribution from agriculture is between 5 and $25 \%$. These regions successfully implemented Green Revolution technologies and gained from the resulting agricultural productivity increases and have substantially reduced poverty and hunger. In these regions, however, there are high levels of income inequality and regional disparities in development. The small farm-dominated East Asian economies of Japan, Taiwan and South Korea are referred to as commercialised agricultural systems, as they have very high per capita incomes and low contributions to GDP from the agricultural sector. In the post-World War II period, these countries saw an increase in farm productivity, and surpluses were effectively transferred to other sectors to aid the structural transformation process. Small farms face different challenges in each of these production systems. By assessing the major characteristics of small farm economies at different stages of structural transformation, we can better understand the economic, nutritional, social and environmental challenges they face. This will enable us to evaluate the magnitude of the challenges to different economies in achieving the SDGs. In the following part of this section, we look at the major challenges faced by smallholder agriculture in each production system; the following section will assess the major interventions needed to remedy them. 


\subsection{Low-Productivity Agricultural Systems}

Countries with low-productivity agricultural systems are beset with poor yields and incomes, despite having large land and/or labour inputs available. Most of these countries are in SSA, where there was low adoption of Green Revolution technologies in staple grains such as wheat, rice and maize (unlike in Asian and Latin American countries). While $82 \%$ of the area under staples in Asia comprised modern high-yielding varieties in 1998, in SSA this was only 27\% (Evenson 2003). Figure 6 shows that the yield for cereals in Africa rose much less than it did in other regions of the world between 1961 and 2017. While cereal yield doubled in SSA, it quadrupled in South Asia, Latin America and Southeast Asia. The main reason is that agricultural production in low-productivity agricultural systems is carried out in marginal environments, with constraining agroclimatic, socio-economic and technological or biophysical constraints, where input-intensive Green Revolution technologies could not be adopted (Pingali et al. 2014). This is coupled with poor access to and provision of essential public goods such as R\&D; factor markets such as credit, seeds, fertilisers and pesticides; and essential infrastructure such as irrigation, storage and roads; affecting production and incentives at the farm level. Development has also been affected by other challenges such as problematic governance, lack of institutional support (e.g. extension services and markets), and low and inelastic demand for agricultural products (Pingali 2010). In recent years, increases in productivity have occurred in these regions via area expansion, not through yield increases

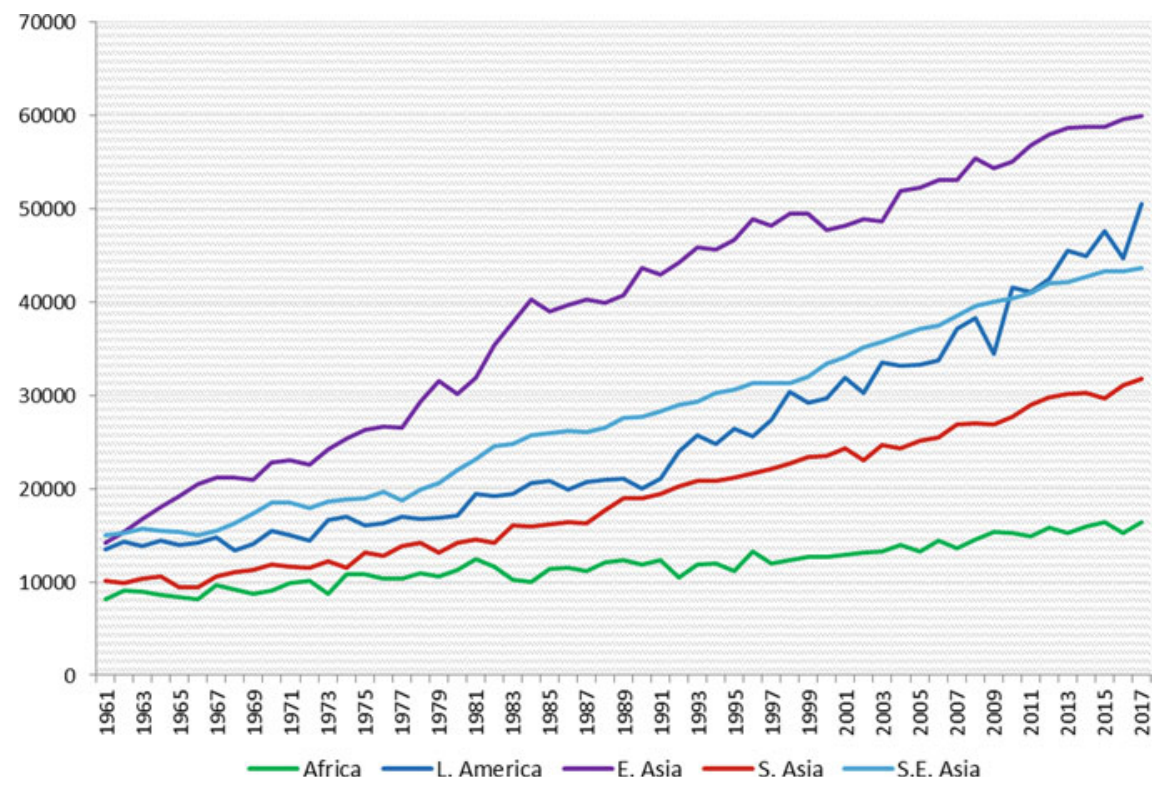

Fig. 6 Cereal yields for selected regions, 1961-2017 (hg/ha). Source FAOSTAT 


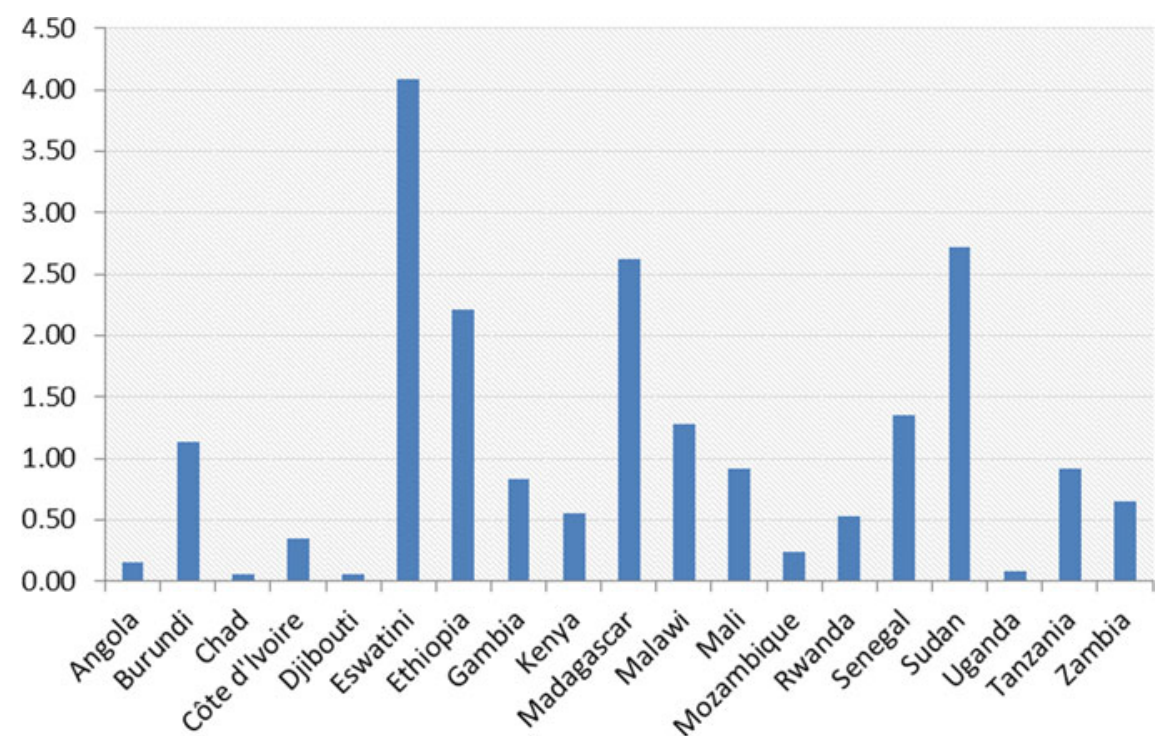

Fig. 7 Percentage of area under irrigation in selected net food-importing African nations, 2016. Source FAOSTAT

(Binswanger-Mkhize and McCalla 2010). Reforms since the 1990s have rectified incentive-distorting policies in agriculture in many countries (Anderson and Masters 2009), but growth and development in the agricultural sector remain challenging.

Environmental and climate change issues are among the biggest challenges in lowproductivity agricultural systems. As it is, $43 \%$ of the African continent is dryland and is prone to extreme weather events and climate change (Cooper et al. 2008; UNDP 2009). According to FAO data, the average area under irrigation in net foodimporting countries in SSA is around 1\% (Fig. 7). Water stress and drought are often exacerbated by land degradation in sub-humid and semi-arid conditions to a greater degree than in purely arid conditions (Adhikari 2013); this only reinforces a higher level of land degradation and low agricultural productivity in SSA (Nkonya et al. 2008). Agroclimatic risks, and the absence of irrigation facilities and technological interventions such as drought-resistant crops, have resulted in high yield gaps in cereals and coarse grains, leading to calorie and micronutrient access problems.

Food and micronutrient access remain a major obstacle in low-productivity agricultural systems. These systems have high prevalence of child stunting, wasting and micronutrient deficiency, and these countries require a significant turnaround to accomplish the goals for hunger and poverty reduction (Pingali et al. 2015). According to FAO, IFAD and WFP (2015), 35.4\% of the world's undernourished live in low-productivity agricultural systems in SSA. Here, despite a $44.4 \%$ drop in incidence since 1991, 19.3\% of children under 5 were undernourished in 2015. The prevalence of stunting decreased from $49.0 \%$ in 1991 to $35.2 \%$ in 2015, while prevalence of wasting reduced from 11.0 to $8.2 \%$. Noteworthy progress was made in the 
MDG era but there is still work to be done, and increased access to calories and micronutrient-rich foods is necessary to address these challenges and meet the SDG targets.

To get agriculture moving, it will be vital to prioritise infrastructure investments in irrigation, watershed management programmes, roads, and marketing facilities and services such as credit and extension. The biggest challenges for achieving the SDGs in low-productivity agricultural systems will be in increasing yields and reducing the impact of agroclimatic risks. Yields can be increased through better access to R\&D, credit and better-quality seeds from factor markets. Agroclimatic risks (including environmental externalities that may contribute to climate change) can be reduced through investments in infrastructure such as roads, irrigation and storage. These investments are crucial for achieving small farm growth and development, especially in low-productivity agricultural systems.

\subsection{Modernising Agricultural Systems}

Countries with modernising agricultural systems successfully implemented Green Revolution technologies and were able to reap the rewards of increased productivity of staple grains - poverty reduction, increased availability of food grains and lower food prices (Pingali 2012). In these economies, agricultural development also stimulated growth in non-agricultural sectors, resulting in rising incomes and urbanisation, which in turn led to rapid diversification of diets and boosted demand for highervalue crops and livestock products (Pingali 2007; Pingali and Khwaja 2004; Reardon et al. 2009; Reardon and Minten 2011). While this has created opportunities for small farms in terms of diversifying into high-value crops that could increase farm-level incomes, larger problems remain in access to key inputs such as credit and R\&D, and to agricultural markets.

Despite the significant changes in nutritional status and access to food that have occurred in the past few decades, issues such as undernourishment, micronutrient deficiency, climatic challenges and interregional inequalities remain major constraints. Figure 8 shows that the prevalence of stunting in South Asia remains the highest globally, higher than in SSA. Despite a 47\% drop since 1991, 32.7\% of children under 5 are stunted. Although East Asia and Pacific, and Latin America and the Caribbean, have significantly reduced the prevalence of stunting, $67.7 \%$ and $61.1 \%$ (respectively) of children under 5 are stunted. Figure 8 also shows that the prevalence of overweight children under 5 is increasing in modernising agricultural systems. Latin America and the Caribbean, followed by East Asia and Pacific, have shown the highest growth in overweight, while South Asia has also witnessed a steady climb. In modernising agricultural systems, the problems of undernourishment, micronutrient deficiency and overnutrition therefore exist simultaneously.

Modernising agricultural systems also have significant regional and interregional differences that have led to unequal growth and development. Figure 9 shows the interregional differences in SSA and modernising agricultural systems. In Latin 
Prevalence of wasting, weight for height (\% of children under 5)

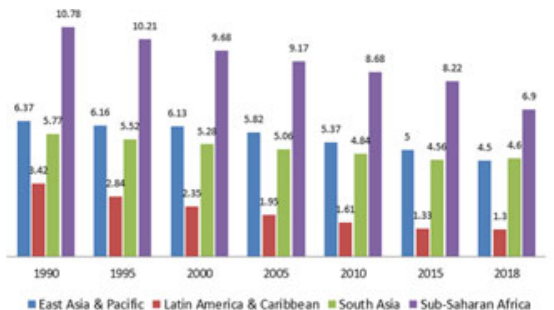

Prevalence of overweight, weight for height (\% of children under 5)

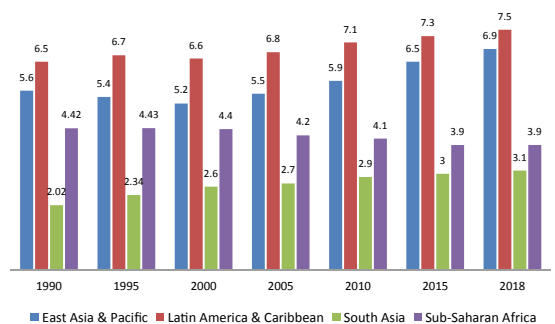

Prevalence of stunting, height for age (\% of children under 5)

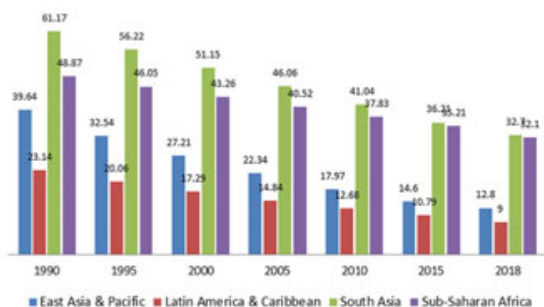

Prevalence of underweight, weight for age ( $\%$ of children under 5)

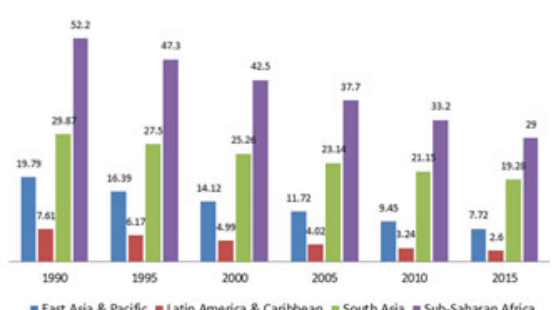

Fig. 8 Trends in wasting, stunting, overweight and underweight children in different regions world. Source FAOSTAT
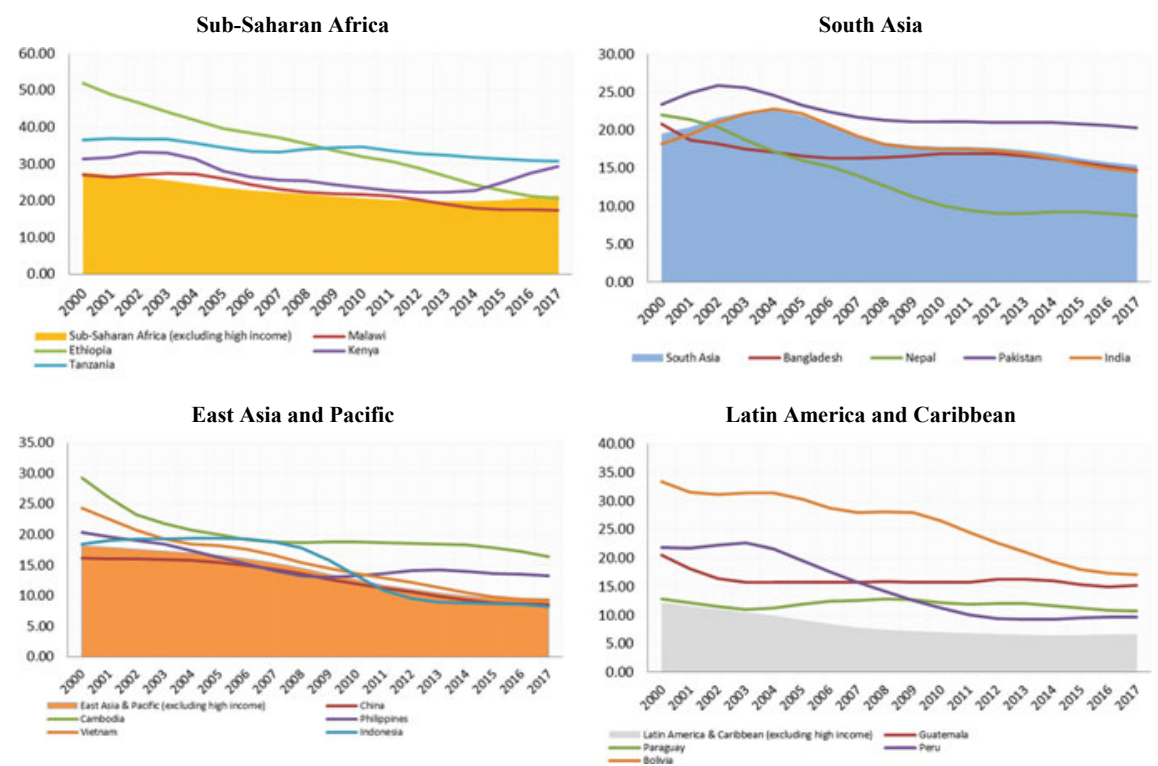

Fig. 9 Prevalence of undernourished $(\%)$ in selected regions and countries. Source FAOSTAT 
America, for example, the small farm economies of Bolivia, Guatemala and Paraguay show higher prevalence of undernourishment compared to regional averages (Fig. 9). In terms of yield gap in cereals, Bolivia and Guatemala are seen to have over $50 \%$ less yield than other countries. Similarly, there are significantly large yield gaps in cereals in South Asia compared to other regions. FAO data show (Fig. 6) average cereal yield to be around 3 tonnes per hectare ( $/ / h a)$ in South Asia, while it is $4.4 \mathrm{t} / \mathrm{ha}$ in Southeast Asia and 6 t/ha in East Asia. Even within countries with modernising agricultural systems, high levels of inequality exist, e.g. in eastern India, western China and northeast Brazil (Pingali 2010). These regions sometimes face similar challenges to low-productivity agricultural systems in SSA, due to geographical constraints such as poor market connectivity and low agroclimatic potential resulting from weather-related stress, e.g. droughts.

Undernourishment (or the prevalence of low access to calorific requirement) is a challenge in modernising agricultural systems. While it is critical to close the yield gap, it is also essential to diversify away from staple cereals, for modernising agricultural systems to achieve improved nutritional outcomes and to meet the rising market demand for diet diversity. Having successfully implemented techniques for cereal intensification using Green Revolution technologies, the development of robust, sustainable and market-oriented production of micronutrient-rich, diverse crops is the logical and necessary next step. To adapt to changing market demand for higher-value crops and other non-staples in ways that would benefit small farms, infrastructure and support resources would be required to enable them to participate in the value chain. The major challenges for modernising systems are in diversifying staple grain systems to improve access to calories, and in addressing micronutrient deficiencies and issues of overnutrition, in order to effectively link small farms to urban food value chains and to address significant interregional disparities within countries so that poverty, hunger, social and environmental SDG goals are achieved.

\subsection{Commercialised Agricultural Systems}

Taiwan, South Korea and Japan are examples of small farm-based economies that have low agricultural GDP and high per capita incomes. These economies underwent successful structural transformation by transitioning out of agriculture-based systems to manufacturing and service-based economies, through effective transfer of surplus out of the agricultural sector. What was unique to these economies, allowing them to develop their small farm sectors into successful enterprises, was that: (a) they underwent a successful land redistribution programme following World War II, making their farm sectors homogeneous (Francks et al. 1999; Ohkawa and Shinohara 1979); (b) these economies were labour-abundant and land-scarce, which is conducive to labour-intensive cultivation, at early stages of development when wages were low and cost of mechanisation was high (Hayami and Ruttan 1971); and (c) institutional arrangements such as cooperatives were set up to remedy problems faced by small 
farms in accessing inputs, credit, agricultural R\&D and output markets (Huang 2006; Kajita 1965; Lin 2006).

In the past few decades, the profitability of small farms in commercialised agricultural systems has been declining, due to rising wages which have reduced the comparative advantage of labour-intensive farming systems (Otsuka et al. 2013). Consequently, assistance to the agricultural sector, in the form of subsidies and trade protection, has risen to keep agriculture artificially attractive (Anderson 2011). Consolidation of landholdings to increase farm size is essential to improve the comparative advantage in these countries. However, laws setting a ceiling on the landholding sizes of households prevent consolidation despite shrinking rural populations and continue to keep farms labour-intensive and small-scale (Otsuka et al. 2016). Modernising agricultural economies, especially India and China, may also follow a similar trajectory, with rising rural wages. The key lessons for small farm production from these economies include the importance of improved access to factor and product markets, and the important role played by institutional arrangements such as cooperatives in enabling these essential services. In the long run, rising wages in the agricultural sector may bring into question the comparative advantage of agriculture in modernising agricultural economies, and in the wake of this it may become essential to revisit the question of land consolidation.

The challenges to tackling hunger, poverty, environmental degradation and social disadvantages in accessing markets differ between small farm-dominated low productivity and modernising agricultural systems. In smallholder-dominated commercialised agricultural systems in Japan, South Korea and Taiwan, many of the disadvantages to small farms were remedied through effective land reforms and institutional interventions in the form of cooperatives. This enabled them to successfully transfer labour and capital resources from the agricultural sector to rapidly initiate structural transformation. In developing countries, improving the viability of small farms is central to the reduction of poverty and hunger and to the structural transformation process. Access to markets is important to incentivise production and diversification and to raise household-level incomes. However, market participation and commercialisation are conditional on transaction costs that influence access to essential factors of production and affect price realisation of produce and commodities sold in the markets. The next section of this chapter assesses various transaction costs that influence access to markets in different production systems, and the interventions that could rectify them to make smallholder farming more sustainable and viable. 


\section{Transaction Costs and the Commercialisation Process-Interventions and Policy Options in Different Production Systems}

Agricultural markets in developing countries are complex institutions, incorporating many forms of production linkages and exchange relations (Benjamin et al. 2002; Harriss-White 1995). These markets comprise factor and product markets. From factor markets, agricultural producers access credit, technology, land and labour for production; in the product markets, they sell their produce. Increased market participation also marks the transition from subsistence-based agriculture to commercialised agriculture. Agricultural commercialisation takes place at the factor (input) and product (output) market levels (von Braun and Kennedy 1994). At the factor market level, commercialisation leads to progressive substitution of non-tradable inputs with tradable inputs used in agricultural production (Pingali and Rosegrant 1995); at the product market level, commercialisation means increased marketability of surplus and diversified products, which increases household-level incomes.

However, the ability to participate in these markets is determined by transaction costs, or the cost of accessing goods and services and making exchanges (Key et al. 2000). These costs limit the ability of smallholders to effectively participate in markets, hindering commercialisation. It is important to identify the characteristics of transaction costs, in order to determine their influence on smallholder production in different production systems, and to design interventions to address them. Smallholder systems are not homogeneous, as various farm, social and behavioural, geographical/locational and crop-specific characteristics influence the conditions under which production and marketing take place (Pingali et al. 2005). Table 3 highlights the main features of these characteristics in low productivity and modernising production systems, and the policy interventions required to address them. In low-productivity systems, high transaction costs of accessing factor markets are the major challenge that hinders productivity growth, resulting in low surpluses, low factor market participation and therefore low commercialisation. In modernising agricultural systems, the transaction costs of accessing product markets are high, and this influences smallholder ability to access specialised value chains and incentivise diversification of production, affecting incomes and growth. In this section, we look at how farm, household, location and crop-specific characteristics determine transaction costs in different production systems, and suggest policy interventions to address them. This is crucial to improve the productivity and incomes of smallholders, which is essential to achieving the SDGs. 
Table 3 Transaction costs and interventions for different production systems

\begin{tabular}{|c|c|c|c|}
\hline Transaction costs & $\begin{array}{l}\text { Production } \\
\text { system }\end{array}$ & Characteristics & Interventions \\
\hline \multirow[t]{2}{*}{ Farm-level } & $\begin{array}{l}\text { Low } \\
\text { productivity }\end{array}$ & $\begin{array}{l}\text { - Low yields and lack of } \\
\text { marketable surplus, } \\
\text { leading to 'low } \\
\text { equilibrium poverty traps' } \\
\text { - Low participation in } \\
\text { factor markets due to high } \\
\text { costs of accessing credit, } \\
\text { inputs and R\&D }\end{array}$ & $\begin{array}{l}\text { - Improved access to capital } \\
\text { markets (credit and insurance) } \\
\text { Provision of R\&D as a public } \\
\text { good along with extension } \\
\text { services and supplementary } \\
\text { inputs }\end{array}$ \\
\hline & Modernising & $\begin{array}{l}\text { - High entry cost for } \\
\text { smallholders in } \\
\text { high-value chains, } \\
\text { limiting } \\
\text { commercialisation } \\
\text { - Low bargaining power in } \\
\text { product markets }\end{array}$ & $\begin{array}{l}\text { - Institutional interventions such } \\
\text { as producer organisations } \\
\text { - Market reforms } \\
\text { - Public-private partnerships }\end{array}$ \\
\hline \multirow[t]{2}{*}{ Household-level } & $\begin{array}{l}\text { Low } \\
\text { productivity }\end{array}$ & $\begin{array}{l}\text { - High participation by } \\
\text { women in agricultural } \\
\text { labour force } \\
\text { - High costs in accessing } \\
\text { factor markets and } \\
\text { productive resources for } \\
\text { women }\end{array}$ & $\begin{array}{l}\text { - Gender-focused policy } \\
\text { initiatives } \\
\text { - Provision of public goods, } \\
\text { credit, R\&D, specifically to } \\
\text { women } \\
\text { - Infrastructure to reduce } \\
\text { women's household workload }\end{array}$ \\
\hline & Modernising & $\begin{array}{l}\text { - Access problems for } \\
\text { women-led households, in } \\
\text { product markets and value } \\
\text { chains } \\
\text { - Disproportionate } \\
\text { workload on farms and at } \\
\text { household level }\end{array}$ & $\begin{array}{l}\text { - Gender-sensitive value chains } \\
\text { and improved access to } \\
\text { product markets } \\
\text { - Investment in gender-focused } \\
\text { labour-saving technologies } \\
\text { - Women's groups to reduce } \\
\text { costs related to scale and low } \\
\text { bargaining power }\end{array}$ \\
\hline \multirow[t]{2}{*}{ Location-specific } & $\begin{array}{l}\text { Low } \\
\text { productivity }\end{array}$ & $\begin{array}{l}\text { Vulnerable to climate } \\
\text { change due to } \\
\text { agroclimatic conditions } \\
\text { - Productivity is low, and } \\
\text { high production risks } \\
\text { make access to credit and } \\
\text { inputs difficult }\end{array}$ & $\begin{array}{l}\text { - Sustainable agricultural } \\
\text { intensification, irrigation } \\
\text { infrastructure } \\
\text { - Climate-focused R\&D in crops } \\
\text { - Combine } \\
\text { production-enhancing } \\
\text { activities with conservation }\end{array}$ \\
\hline & Modernising & $\begin{array}{l}\text { - Connectivity and distance } \\
\text { to markets determines } \\
\text { cost of marketing } \\
\text { - Location determines } \\
\text { ability to form contracts } \\
\text { in high-value chains }\end{array}$ & $\begin{array}{l}\text { - Infrastructure of connectivity } \\
\text { and storage } \\
\text { - Specialised cold chain for } \\
\text { perishables }\end{array}$ \\
\hline
\end{tabular}


Table 3 (continued)

\begin{tabular}{l|l|l|l}
\hline Transaction costs & $\begin{array}{l}\text { Production } \\
\text { system }\end{array}$ & Characteristics & Interventions \\
\hline Crop-specific & $\begin{array}{l}\text { Low } \\
\text { productivity }\end{array}$ & $\begin{array}{l}\text { - High cost of adopting } \\
\text { crops and livestock } \\
\text { programmes hinders } \\
\text { diversification and results } \\
\text { in low commercialisation }\end{array}$ & $\begin{array}{l}\text { - Aid commercialisation } \\
\text { through policy deregulation } \\
\text { Investment in infrastructure, } \\
\text { capital markets and R\&D }\end{array}$ \\
\cline { 2 - 4 } Modernising & $\begin{array}{l}\text { - Policy favouring } \\
\text { production and marketing } \\
\text { of staple grains reduces } \\
\text { comparative advantage of } \\
\text { other crops, reducing } \\
\text { incentives to diversify }\end{array}$ & $\begin{array}{l}\text { - Crop-neutral agricultural } \\
\text { policy } \\
\text { Infrastructure development to } \\
\text { connect to high-value chains } \\
\text { and bring a private sector } \\
\text { response }\end{array}$ \\
\hline
\end{tabular}

\subsection{Farm-Specific Costs and Interventions in Different Production Systems}

The volume of marketable surplus generated by smallholders determines their ability to participate in both factor and product markets. Some farms are either subsistence or semi subsistence-based, as they produce only for household consumption or they have limited engagement with markets (either buying or selling). Other smallholders are more commercialised, as they both buy and sell in the markets (de Janvry et al. 1991). Farm-specific transaction costs are costs that influence smallholder participation in markets determined by the production status of farms. Small farms may not participate in, or may have difficulty accessing, both factor and product markets due to limited surplus creation.

In low-productivity systems, there is a prevalence of low equilibrium poverty traps, where low surplus leads to low market participation, resulting in low incentives to improve production, again leading to poor yields (Barrett 2008). Small landholdings with low yields have higher costs associated with accessing institutional credit, due to high production risks and low collateral. Low access to credit in turn hinders the ability to access quality inputs such as seeds with high yield potential, fertiliser and pesticides, and R\&D that may reduce risks and uncertainties. The major policy agenda in low-productivity agricultural systems requires the reduction of transaction costs for accessing factor markets, beginning with capital (credit and insurance), followed by inputs and extension services that will enable crop intensification (increased output per unit of input). Improving capital market access will increase ability to access inputs and safeguard against production risks. Smallholder access to R\&D was critical to the success of the Green Revolution. In low-productivity agricultural systems, similar initiatives are needed, along with public services such extension and information dissemination to increase adoption of yield-increasing technologies.

In modernising agricultural systems, transaction costs in product markets need to be reduced for better price realisation and improved farm incomes for smallholders. 
In many of these economies, demand for high-value agricultural products has created opportunities for small farms to diversify production and realise better profits by participating in value chains. However, smallholder exclusion, due to transaction costs characterised by bureaucratic, monitoring and management costs, causes small farms to be discriminated against in favour of larger farms when forming contracts, limiting their participation (Dolan and Humphrey 2000; Hazell et al. 2010; Reardon and Berdegué 2002; Reardon et al. 2003; Swinnen and Maertens 2007). Policy interventions in modernising agricultural systems need to promote initiatives to streamline marketing chains and enable forward and backward linkages for smallholders, through contracts in high-value chains. Institutional interventions such as producer organisations and cooperatives have helped to provide inputs, reduce transaction costs and also form market linkages (Barrett et al. 2012; Bellemare 2012; Boselie, Henson and Weatherspoon 2003; Briones 2015; Reardon et al. 2009; Schipmann and Qaim 2010). Promotion of these institutions will help smallholders to mitigate some of the transaction costs associated with market entry, as it addresses problems associated with economies of scale. Incentives are also needed in these production systems to attract public-private partnership and to collaborate with civil society organisations to enable such linkages. Productivity and income growth, through increased market participation by smallholder farmers, are central to achieving the goals for poverty (SDG 1 and SDG 8) and nutrition (SDG 2 and SDG 3), and the social goal of reducing inequalities within and among countries (SDG 10).

\subsection{Household-Specific Costs and Interventions in Different Production Systems}

Behavioural and social characteristics influence household-level decision-making and smallholder ability to access factor and product markets (Pingali et al. 2007). The costs of market participation determined by social and behavioural characteristics are referred to as household-specific transaction costs. The behavioural characteristics that influence the cost of engaging with markets are the household's level of aversion to risk and uncertainty, entrepreneurial ability and technical ability (Barrett et al. 2012). In a more complex way, the social characteristics that influence market access and participation are social networks, caste (Sen 2000; Thorat 2009), age, gender (Agarwal 1995, 2010; RFST 2005) and education (Narayanan 2014). Here, we will look specifically at the issue of gender and its influence on transaction costs in smallholder agricultural production.

Women are among the largest groups of landless labourers, and the largest group dispossessed or with restricted access to land (Agarwal 1994; Deere and Leon 2001). They also represent two-thirds of livestock keepers (Thornton et al. 2002) and 30\% of labour in fisheries (FAO 2011). Despite having an important role in production, studies have also shown women to face high costs in accessing capital, engaging in entrepreneurial activities (Fletschner and Carter 2008) and adopting technological 
inputs and mechanisation (FAO 2006). Therefore, in many developing countries, women-led households have lower yields and incomes, due to poor access to markets and productive resources (Croppenstedt et al. 2013), affecting their contributions to agricultural productivity (FAO 2011). Women also provide non-marketable goods and services at the household level, such as gathering water and fuel, child health and nutrition and also subsistence crop production which is essential for household welfare (Floro 1995). In this context, time-saving measures are relevant to women's workloads, income and household-level welfare.

In low-productivity agricultural systems, women's participation in the agricultural labour force is higher than the global average (Croppenstedt et al. 2013). Therefore, it is crucial to close the gender gap and address gender-specific transaction costs and constraints to agricultural production, to increase agricultural productivity and women's empowerment. Improving access to factors of production, such as cultivable land and institutional credit, is central to providing women with control over productive resources in agriculture. Better access to public goods such as tap water, and other private goods such as clean fuel for household use, helps to improve women's health, reduce drudgery and free up labour for more productive activities. Agricultural policies related to natural resource management, access to inputs and technology, and production affect male-headed households and female-headed household differently, and therefore, there is a need for a more gendered policy focus in agriculture (FAO 2011). It is essential to promote women's self-help groups (SHGs) for education, information dissemination, access to microcredit, provision of essential public goods and support for production-based activities. Investment is needed in infrastructure and capital for access to tap water and clean fuels for cooking, to free up time for more productive activities. Time-saving measures can also deliver multigenerational nutritional benefits to households with women using their freed time for other productive activities. This will also help to improve productivity and surplus creation in women-led household in low-productivity agricultural systems.

The two major interventions needed in modernising agricultural systems, to address gender-specific challenges, are improved access to product markets and labour savings for rural women. With regard to access to product markets, studies have shown that women involved in both traditional and modern crop production and marketing face considerable disadvantages and risks (Cabezas et al. 2007). A more gender-sensitive value chain is required to address access problems in markets (Rubin and Manfre 2014; Nakazibwe and Pelupessy 2014; Quisumbing et al. 2015). As women are often involved in agricultural labour and non-marketed household labour, measures to improve the labour efficiency and productivity of women will enable cost savings and free up time. Labour-saving technology needs to be implemented through mechanisation in agriculture, to reduce drudgery.

Policy initiatives to promote women's organisations, and build capacity to make them self-sustaining, is important to tackle gender-specific challenges in production and marketing. Gender-sensitive value chains that facilitate women's participation in high-value markets are essential. Supporting women's groups to form contracts, and building in support systems to enforce contracts and prevent hold-ups, is important to enable market linkages between farm and market, and to improve incomes through 
better price realisation. Collaboration with state and civil society organisations is vital to promote and empower women's producer organisations and SHGs. Mechanisation, like marketing, is scale-sensitive and collective action to enable joint access to labour-reducing machinery is again vital. Targeting of mechanisation in womendominated activities in agriculture, such as transplantation and harvesting, needs to take precedence in modernising agricultural systems. It is important to address the household-specific transaction costs that influence women-led smallholder households, in improving productivity and agricultural growth to meet the poverty goals (SDG 1 and SDG 8). Improving time use and efficiency will play an important role in meeting the nutritional goals (SDG 2 and SDG 3) in different production systems. Economic empowerment of women is also central to meeting the social goals (SDG 5 and SDG 10).

\subsection{Location-Specific Transaction Costs in Different Production Systems}

Seasonality and geographical dispersion are major influences in agricultural production, making the location of farms an important determinant of agroclimatic risks, cost of production and marketing in different production systems. In low-productivity agricultural systems, climate change issues and environmental externalities are a pressing concern, as much of the cultivated area is unirrigated and/or semi-arid. In the long run, rising temperatures will affect yields and farm-level revenues in many of these regions (Kurukulasuriya et al. 2006). Mitigating the effects of climate change, and the need to simultaneously increase yield, will pose a major challenge to the growth and development of agricultural sectors in low-productivity agricultural systems. It is important to achieve agricultural intensification without increasing negative externalities of agricultural production, such as diminishing biodiversity, increasing GHG emissions, land and water degradation. Policy interventions to promote sustainable agricultural intensification are essential, to manage the dual challenge of climate change and productivity growth (Matson et al. 1997; Pretty et al. 2011). In the formulation of agricultural policy, it will prove to be essential to supplement agricultural productivity programmes with agroforestry for carbon sequestration, soil conservation and watershed management programmes to limit land degradation and promote water conservation (Lipper et al. 2006; Pretty et al. 2011). To offset the current impacts of climate change, investment is needed in R\&D to promote heat and drought-resistant crops, technologies and infrastructure such as micro-irrigation systems. It is also crucial to make these technologies easily accessible to smallholders. These interventions are also relevant in modernising agricultural systems that have infrastructural disadvantages related to agroclimatic conditions. Therefore, farm-level transaction costs influenced by economies of scale, and household-level transaction costs determined by gender and social status, also need to be rectified to enable access to interventions to mitigate locational disadvantages. 
In modernising agricultural systems, location-specific factors influence small farm linkages. In vertical coordination, agents are selective about farmers' eligibility to participate in contracts, depending on the location of farms (areas with good retail and processing infrastructure) (Martinez 2002a; Mishra and Chand 1995; Trebbin and Franz 2010). Procurement distance is also an important determinant in value chains of perishable products such as milk, poultry, eggs and meat (Martinez 1999, $2002 \mathrm{~b}$ ). In the context of the emerging relevance of organised retail, these factors determine whether an area has high or low potential for market linkages (Pingali et al. 2007). The preference by retailers for high potential areas can lead to market segmentation and exclusion of some farms (David and Kusterer 1990; Little and Watts 1994) and can increase regional disparity in modernising agricultural systems. Policy interventions to create infrastructural public goods, and mitigate locational disadvantages, in low potential areas will help to decrease regional disparity in market access. Increased investment by the state to expand storage facilities and cold chains and improve connectivity is also vital, to reduce wastage and increase marketing options for smallholders. These interventions in infrastructure are often needed for a private sector response to engage in markets and enable the emergence of vertical coordination where farms can directly connect with retail. Location-specific transaction costs can lead to higher degradation of land and natural resources - without proper management practices in these resources - and increase wastage in food products; it is vital to mitigate them for responsible and sustainable production and consumption. Therefore, addressing these costs, and factors that contribute to them, is central to achieving the environmental and poverty goals.

\subsection{Crop-Specific Transaction Costs in Different Production Systems}

The production and marketing of different crops have varying levels of transaction costs associated with them. The level of these costs and returns incentivises the adoption of crops at the farm level. Agricultural produce can be classified as commodities or products, where commodities are 'standardised agricultural products that have had little or no processing and often are raw materials for further procession' (Schaffner et al. 1998, p. 6). Grains and pulses are often considered to be commodities. Products are produce or subsets of a given commodity that is highly differentiated based on attributes (organic, processed, branded, variety, perishability) (Reardon and Timmer 2007). Fruits and vegetables, milk and dairy products, and meat are all considered products. Diversifying away from staples such as wheat, rice and maize, and towards higher-value crops is an integral part of commercialisation. This changes access to factor and product markets; commodities and products are influenced by different sets of production, marketing and transaction costs. Policy also plays an important role in influencing transaction costs. Subsidies and price support can lower production and marketing costs for certain crops, to distort incentives in their favour. 
In low productive agricultural systems, diversification initially involves the addition of crops (coarse grains, micronutrient-dense legumes, pulses, vegetables and fruit) and livestock programmes to small farms, before moving towards specialised production (Pingali and Rosegrant 1995). A diversified production basket would enable better income opportunities, especially through livestock production and better access to nutritious food groups through the cultivation of coarse grains and pulses. Reducing transaction costs in accessing factor markets therefore becomes vital for diversification. Government policy plays a central role in aiding the commercialisation process, by developing capital markets to increase rural investments and improve access to credit and insurance; enabling access to R\&D in income-enhancing technologies; continuing deregulation of the agricultural sector; and promoting health and nutrition-based initiatives to supplement the transition.

In modernising agricultural systems, diversification of production towards highervalue, market-oriented produce is needed for income growth. The major challenges for crop diversification have been both unfavourable policy and poor market access. In many countries that successfully implemented Green Revolution technologies, there is a policy bias favouring staple grains, especially wheat, rice and maize, through input subsidies and price support (Pingali 2015). Although they were initially incentives to adopt high-yielding technologies by lowering factor, production and marketing costs of staples, in the long run they have distorted farm and market-level incentives to diversify (ibid.). The costs of adopting more nutrition-rich or more commercially viable crops are relatively higher, due to subsidies for staples. In terms of market access, as products are highly differentiated, they require higher labour inputs, monitoring requirements, higher levels of credit, quality inputs and extension services. Due to higher transaction costs in accessing markets and forming contracts, there are low incentives for smallholders to commercialise.

Both policy and market interventions are required to rectify crop-specific transaction costs. At the policy level, crop-neutral agricultural policy is needed to level the playing field and enable better smallholder response to market and price signals (Pingali 2015). This entails the rollback of excessive support to staple grains in all production systems. Linking small producers to value chains is also important to enable fair price realisation and reduce market failures. It has been noted that small farms participating in value chains have both direct and indirect gains (Swinnen and Maertens 2007). The direct gains accrue through increase in productivity, improvement in quality and rise in household-level incomes (Birthal et al. 2009; Dries et al. 2009; Ramaswami et al. 2009). The indirect effects have been reduced risks in production, increased access to credit and technology, improved market participation and productivity spillovers to other crops (Bellemare 2012; Swinnen and Maertens 2007). Therefore, effective linkages to product markets play an important role in incentivising production, diversification and intensification in all production systems.

In this section, we looked at how transaction costs determined by farm, household, location and crop characteristics influence the ability of smallholders to access factor and product markets influencing livelihoods. These costs have varying influences on agricultural production and marketing in different farming systems, and 
therefore, policy and market interventions need to be tailored to specific challenges if various poverty, nutritional, social and environmental SDGs are to be met. In lowproductivity agricultural systems, sustainable intensification of agriculture is needed to increase productivity, while keeping check on environmental externalities. The biggest challenge for these systems is the transaction costs associated with accessing factor markets. Policy interventions are needed to reduce the cost of accessing credit, quality inputs and R\&D to support intensification and diversification, enabling income growth and nutritional outcomes. Technology enabling the production of high-yielding, heat and drought-resistant crops is also needed for sustainable production in the wake of rising temperatures and changing climate. In modernising production systems, with consumption demand changing to higher-value products, access to product markets determines the ability of smallholders to produce for these markets and improve household-level incomes. Therefore, it is also important to link small producers to value chains, and this requires investment in infrastructure for connectivity and storage. Institutional interventions, in the form of cooperatives and aggregation models, have worked well in rectifying smallholder disadvantages in commercialised agricultural systems. There is a need for more research and support in promoting these organisations more widely, as they have proven to reduce transaction costs and rectify smallholder disadvantages. In both production systems, women play an important role in agricultural production, and in producing non-marketable goods and services at the household level that increase welfare. Social emancipation and economic empowerment are important to improve income and nutritional outcomes and to meet the social goal of reduced gender inequality.

\section{Conclusion}

The 2030 Agenda for Sustainable Development approved by the UN member states set an ambitious goal to end poverty, protect the planet and ensure prosperity for all global citizens by the year 2030. The 17 SDGs have 169 targets designed to take a holistic approach to addressing the social, economic and environmental aspects of sustainable development. As the majority of global agricultural production takes place on small farms, and about 2 billion of the world's poor directly depend on the sector for their livelihood, working as cultivators or wage-earning labourers, the centrality of small farm development and growth to achieving the SDGs is undeniable. Nine of the 17 SDGs, pertaining to poverty eradication (SDG 1 and SDG 8), hunger and nutrition (SDG 1 and SDG 3), social emancipation and inequality (SDG 5 and SDG 10) and the environment (SDG 12, SDG 13 and SDG 15), are directly linked to the agricultural sector.

Small farms are heterogeneous and the production challenges they face are determined by their geography and the stage of structural transformation. Countries with low per capita incomes and a high share of GDP coming from agriculture are considered low-productivity agricultural systems, while countries with medium-level per 
capita incomes and less than $30 \%$ of GDP contribution from agriculture are considered modernising agricultural systems. Countries with high per capita income tend to be dominated by commercialised agricultural systems. In low productivity and modernising agricultural systems, productivity growth leading to surplus creation is essential to improve farm-level incomes and household-level welfare, to realise the SDGs. Achieving this requires increased market participation or commercialisation. However, market participation is determined by transaction costs and when these costs are high, commercialisation is hindered, affecting productivity and growth.

The process of agricultural commercialisation in developing countries is essential to meeting the poverty, nutritional, social and environmental SDGs. In this chapter, we use a transaction cost framework to assess the major costs that constrain small producer agriculture in different production systems, in order to identify specific areas of intervention needed to address them. In low-productivity agricultural systems, where yield increase is crucial to meet hunger and nutritional goals, improved access to factor markets is most important. Capital markets to access credit and insurance, R\&D access to adopt high-yielding and climate change-resistant crops, and extension services to aid in diversification and effective utilisation of resources, are essential for increasing productivity while reducing environmental externalities. In modernising agricultural systems that have already witnessed productivity gains from the Green Revolution, access to product markets is essential. Here, the ability to access highvalue chains, and form contacts with retailers and other end-users, is important to meet market opportunities and improve the incomes of smallholders. In both production systems, improving women's access to factor markets and product markets is also essential for productivity and household-level welfare. Time-saving measures are important to reduce drudgery for women in the production of both marketable and non-marketable goods and services. Improving access to clean water and fuel is important to save time at the household level, while promoting mechanisation would help to reduce labour time used in agricultural production.

Policy interventions are needed to rectify transaction costs and enable commercialisation. In low-productivity agricultural systems, policy is needed to reduce the cost of accessing credit, quality inputs and R\&D to support intensification and diversification. In modernising agricultural systems, it is also important to rectify subsidies favouring wheat, rice and maize, to promote a crop-neutral agricultural policy, incentivising farm-level diversification towards other crops. A more gender-sensitive approach to agricultural policy is essential in all developing countries to address the social disadvantage women face in agricultural production and access to markets. Promoting aggregation models such as the cooperatives will also prove crucial, to rectify some of the scale disadvantages to smallholders in accessing markets. Gendered aggregated group such as SHGs will continue to play an important role in addressing gender-specific access problems, especially with capital markets and technology. 


\section{References}

Adhikari, B. (2013). Poverty reduction through promoting alternative livelihoods: Implications for marginal drylands. Journal of International Development, 25(7), 947-967. https://doi.org/10. 1002/jid.1820.

Agarwal, B. (1994). A field of one's own: Gender and land rights in south Asia. Cambridge: Cambridge University Press.

Agarwal, B. (1995). Gender and legal rights in agricultural land in India. Economic and Political Weekly, 30(12), A39-A56.

Agarwal, B. (2010). Rethinking agricultural production collectivities. Economic and Political Weekly, 45(9).

Anderson, K. (2011). Government distortions of agricultural prices: Lessons from rich and emerging economies. In K. Otsuka \& K. Kalirajan (Eds.), Community, market, and state. Hampshire: Palgrave Macmillan.

Anderson, K., \& Masters, W. A. (2009). Distrotions to agricultural incentives in Africa. Washington D.C.: The World Bank.

Bardhan, P. (1973). Size, productivity and returns to scale: An analysis of farm-level data in Indian agriculture. Journal of Political Economy, 81(6), 1370-1386.

Barrett, C. B. (2008). Smallholder market participation: Concepts and evidence from eastern and southern Africa. Food Policy, 33(4), 299-317. https://doi.org/10.1016/j.foodpol.2007.10.005.

Barrett, C. B., Bachke, M. E., Bellemare, M. F., Michelson, H. C., Narayanan, S., \& Walker, T. F. (2012). Smallholder participation in contract farming: Comparative evidence from five countries. World Development, 40(4), 715-730. https://doi.org/10.1016/j.worlddev.2011.09.006.

Basu, S. (1997). Why institutional credit agencies are reluctant to lend to the rural poor: A theoretical analysis of the Indian rural credit market. World Development, 25(2), 267-280. https://doi.org/ 10.1016/S0305-750X(96)00103-9.

Bellemare, M. F. (2012). As you sow, so shall you reap: The welfare impacts of contract farming. World Development, 40(7), 1418-1434. https://doi.org/10.1016/j.worlddev.2011.12.008.

Benjamin, D. (1995). Can unobserved land quality explain the inverse productivity relationship? Journal of Development Economics, 46, 51-84.

Benjamin, D., Reardon, T., Stamoulis, K. G., \& Winters, P. (2002). Promoting farm/non-farm linkages for rural development-Case studies from Africa and Latin America. Rome: Food and Agriculture Organisation, The United Nations.

Besley, T. (1995a). Property rights and investment incentives: Theory and evidence from Ghana. Journal of Political Economy, 103(5), 903-937.

Besley, T. (1995b). Savings, credit and insurance. In J. Behrman \& T. N. Srinivasan (Eds.), The handbook of developmental economics (pp. 2124-2207). Amsterdam: Elsevier Science Publishers, B.V.

Bhaduri, A. (1977). On the formation of usurious interest rates in backward agriculture. Cambridge Journal of Economics, 1(4), 341-352. Retrieved from http://www.jstor.org/stable/23596381.

Bhalla, S. S., \& Roy, P. (1988). Mis-specification in farm productivity analysis: The role of land quality. Oxford Economic Papers, 40(1), 55-73.

Binswanger-Mkhize, H., \& McCalla., A. F. (2010). The changing context and prospects for agricultural and rural development in Africa. In P. L. Pingali \& R. E. Evenson (Eds.), Handbook of agricultural economics (4th ed., Vol. 4, pp. 3571-3712). Oxford: Wlsevier B.V.

Binswanger, H. P., \& Rosenzweig, M. R. (1986). Behavioural and material determinants of production relations in agriculture. Journal of Development Studies, 22, 503-539.

Birthal, P. S., Jha, A. K., Tiongco, M. M., \& Narrod, C. (2009). Farm-level impacts of vertical coordination of the food supply chain: Evidence from contract farming of milk in India. Indian Journal of Agricultural Economics, 64(3), 481-496. Retrieved from http://search.proquest.com/ docview/201483208? accountid=10267.

Boselie, D., Henson, S., \& Weatherspoon, D. (2003). Supermarket procurement practices in developing countries: Redefining the roles of the public and private sectors. American Journal of 
Agricultural Economics, 85(5), 1155-1161. Retrieved from http://www.jstor.org.proxy.library. cornell.edu/stable/1244887.

Briones, R. M. (2015). Small farmers in high-value chains: Binding or relaxing constraints to inclusive growth? World Development, 72, 43-52. https://doi.org/10.1016/j.worlddev.2015. 01.005 .

Byerlee, D., de Janvry, A., \& Sadoulet, E. (2009). Agriculture for development: Toward a new paradigm. Annual Review of Resource Economics, 1, 15-31.

Cabezas, A., Reese, E., \& Waller, M. (2007). The wages of empire: Globalization, state transformation, and women's poverty (A. Cabezas, E. Reese, \& M. Waller, Eds.). Boulder CO: Paradigm Publishers.

Carletto, C., Corral, P., \& Guelfi, A. (2017). Agricultural commercialization and nutrition revisited: Empirical evidence from three African countries. Food Policy, 67, 106-118. https://doi.org/10. 1016/j.foodpol.2016.09.020.

Carr, M., \& Hartl, M. (2010). Leightening the load: Labor saving technologies and practices for rural women.

Chand, R., Prasanna, L. P. A., \& Singh, A. (2011). Farm size and productivity: Understanding the strengths of smallholders and improving their livelihoods. Economic and Political Weekly, 46(26\&27), 5-11.

Christiaensen, L., Demery, L., \& Kuhl, J.(2006). The role of agriculture in poverty reduction an empirical perspective. Policy Research Working Papers. The World Bank. http://doi.org/doi:10. 1596/1813-9450-4013

Cooper, P. J. M., Dimes, J., Rao, K. P. C., Shapiro, B., Shiferaw, B., \& Twomlow, S. (2008). Coping better with current climatic variability in the rain-fed farming systems of sub-Saharan Africa: An essential first step in adapting to future climate change? Agriculture, Ecosystems \& Environment, 126(1-2), 24-35. https://doi.org/10.1016/j.agee.2008.01.007.

Croppenstedt, A., Goldstein, M., \& Rosas, N. (2013). Gender and agriculture: Inefficiencies, segregation, and low productivity traps. World Bank Research Observer, 28(1), 79-109. https://doi. org/10.1093/wbro/lks024.

David, G., \& Kusterer, K. (1990). Small farmer, big business-contract farming and rural development. London: Macmillan.

de Janvry, A., Fafchamps, M., \& Sadoulet, E. (1991). Peasant household behaviour with missing Markets: Some paradoxes Explained. Economic Journal, 101(409).

Deere, C. D., \& Leon, M. (2001). Empowering women. Land and property rights in Latin America. Pittsburgh: University of Pittsburgh Press.

Distefano, F. (2013). Understanding and integrating gender issues into livestock projects and programmes: A checklist for practitioners. Rome: Italy.

Dolan, C., \& Humphrey, J. (2000). Governance and trade in fresh vegetables: The impact of UK supermarkets on the African horticulture industry. Journal of Development Studies, 37(2), 147176.

Dries, L., Germenji, E., Noev, N., \& Swinnen, J. F. M. (2009). Foreign direct investment, vertical integration, and local suppliers: Evidence from the Polish dairy sector. World Development, 37(11), 1742-1758.

Eastwood, R., Lipton, M., \& Newell, A. (2010). Farm size. Handbook of Agricultural Economics, 4, 3323-3397. https://doi.org/10.1016/S1574-0072(09)04065-1.

Eswaran, M., \& Kotwal, A. (1986). Access to capital and agrarian production organisation. Economic Journal, 96(382), 482-498. Retrieved from http://onlinelibrary.wiley.com/journal/10. 1111/\%28ISSN\%291468-0297/issues.

Evenson, R. E. (2003). Crop variety improvement and its effect on productivity: The impact of international agricultural research. In R. E. Evenson \& D. Gollin (Eds.), (pp. 447-472). Cambridge, MA: CABI.

Fan, S., \& Chan-Kang, C. (2005). Is small beautiful? Farm size, productivity, and poverty in Asian agriculture. Agricultural Economics, 32, 135-146. https://doi.org/10.1111/j.0169-5150. 2004.00019.x. 
Fan, S., Hazell, P., \& Thorat, S. (2000). Government spending, growth and poverty in rural India. American Journal of Agricultural Economics, 82(4), 1038-1051. Retrieved from http://www. jstor.org/stable/1244540

FAO. (2006). Agriculture, trade negotiations and gender. Rome: Italy.

FAO. (2011). The role of women in Agriculture (ESA Working Paper No. 11-2). Retrieved from www.fao.org/economic/esa.

FAO. (2014). State of food and agriculture. Rome, Italy. Retrieved from http://www.fao.org/3/ai4040e.pdf.

FAO, IFAD, \& WFP. (2015). The state of food insecurity in the world 2015. Meeting the 2015 international hunger targets: Taking stock of uneven progress. Rome, Italy.

Feder, G. (1985). The relation between farm size and farm productivity. Journal of Development Economics, 18, 297-313.

Fletschner, D., \& Carter, M. R. (2008). Constructing and reconstructing gender: Reference group effects and women's demand for entrepreneurial capital. The Journal of Socio-Economics, 37(2), 672-693. http://doi.org/10.1016/j.socec.2006.12.054.

Floro, M. S. (1995). Economic restructuring, gender and the allocation of time. World Development, 23(11), 1913-1929. https://doi.org/10.1016/0305-750X(95)00092-Q.

Fontana, M. (2009). The gender effects of trade liberalisation in developing countries: A review of the literature. In M. Bussolo \& R. De Hoyos (Eds.), Gender aspects of the trade and poverty nexus: A micro-macro approach. Palgrave Macmilan: Baskingstoke.

Francks, P., Boestel, J., \& Kim, C. H. (1999). Agriculture and economic development in east Asiafrom growth to protectionism in Japan, Korea and Taiwan. London: Routledge.

Ghosh, J. (2013). Microfinance and the challenge of financial inclusion for development. Cambridge Journal of Economics, 37(6), 1203-1219.

Ghosh, P., Mookherjee, D., \& Ray, D. (2001). Credit rationing in developing countries: An overview of the theory. In D. Mookherjee \& D. Ray (Eds.), Readings in the theory of economic development (pp. 283-301). Malden, MA: Blackwell Publishing Ltd.

Goldstein, M., \& Udry, C. (2005). The profits of power: Land rights and agricultural investment in Ghana (Economic Growth Center Working Paper No. 929). New Haven, CT.

Harriss-White, B. (1995). Maps and landscapes of grain markets in South Asia. In J. Harriss, J. Hunter, \& C. M. Lewis (Eds.), The new institutional economics and Third World development. London ; New York: Routledge.

Hayami, Y., \& Ruttan, V. W. (1971). Agricultural development: An international perspective. Baltimore: Johns Hopkins University Press.

Hazell, P., Poulton, C., Wiggins, S., \& Dorward, A. (2010). The future of small farms: Trajectories and policy priorities. World Development, 38(10), 1349-1361. https://doi.org/10.1016/j. worlddev.2009.06.012.

Huang, J. (2006). Taiwan in transformation, 1895-2005: The challenge of a new democracy to an old civilization. New Jersey: Transaction Publishers.

Ivanic, M., \& Martin, W. (2008). Implications of higher global food prices for poverty in lowincome countries1. Agricultural Economics, 39, 405-416. https://doi.org/10.1111/j.1574-0862. 2008.00347.x.

Johnson, N. L., \& Ruttan, V. W. (1994). Why are farms so small? World Development, 22(5), 691-706. https://doi.org/10.1016/0305-750X(94)90044-2.

Jost, C., Kyazze, F., Naab, J., Neelormi, S., Kinyangi, J., Zougmore, R., ... Kristjanson, P. (2016). Understanding gender dimensions of agriculture and climate change in smallholder farming communities. Climate and Development, 8(2), 133-44.

Kajita, M. (1965). Land policy after land reforms in Japan. Developing Economies, 3(1), 88-105. https://doi.org/10.1111/j.1746-1049.1965.tb00749.x.

Key, N., Sadoulet, E., \& de Janvry, A. (2000). Transactions costs and agricultural household supply response. American Journal of Agricultural Economics, 82(2), 245-259. https://doi.org/10.1111/ 0002-9092.00022. 
Kraemer, K., \& Zimmermann, M. (2007). The guidebook nutritional anemia. Basel, Switzerland: Sight and Life Press.

Kurukulasuriya, P., Mendelsohn, R., Hassan, R., Benhin, J., Deressa, T., Diop, M., ... Dinar, A. (2006). Will African agriculture survive climate change? The World Bank Economic Review, 20(3), 367-388. Retrieved from https://doi.org/10.1093/wber/lhl004.

Leichenko, R. M., \& O'Brien, K. L. (2002). The dynamics of rural vulnerability to global change: The case of southern Africa. Mitigation and Adaptation Strategies for Global Change, 7(1), 1-18. https://doi.org/10.1023/A:1015860421954.

Lin, D. (2006). Agricultural cooperatives in Taiwan. In 2006 FFTC-NACF International Seminar on Agricultural Cooperatives in Asia: Innovations and Opportunities in the 21 st Century. Seoul, Korea. Retrieved from http://www.agnet.org/htmlarea_file/activities/201.

Lipper, L., Pingali, P., \& Zurek, M. (2006). Less-favoured areas: looking beyond agriculture towards ecosystem services. In R. Ruben, J. Pender, \& A. Kuyvenhoven (Eds.), Sustainable poverty reduction in less-favoured areas: Problems, options and strategies (pp. 442-460). Wallingford, UK: CABI.

Little, P., \& Watts, M. (1994). Living under contract: Contract farming and agrarian transformation in Sub-Saharan Africa. Madison, WI: University of Wisconsin Press.

Martinez, S. W. (1999). Vertical coordination in the pork and broiler industry (AER No. 777). Washington DC.

Martinez, S. W. (2002a). A comparison of vertical coordination in the US poultry, egg, and pork industries (Agriculture Information Bulletin No. 747-5). Washington DC.

Martinez, S. W. (2002b). Vertical coordination of Marketing systems: Lessons from the poultry, egg and pork industries (Agricultural Economic Report No. 807).

Matson, P. A., Parton, W. J., Power, A. G., \& Swift, M. J. (1997). Agricultural intensification and ecosystem properties. Science, 277(5325), 504-509. https://doi.org/10.1126/science.277. 5325.504 .

Mazumdar, D. (1965). Size of farm and productivity-A problem of indian peasant agriculture. Economica, 32(126), 161-173.

Mishra, S., \& Chand, R. (1995). Public and private capital formation in Indian agriculture: Comments on complementarity hypothesis and others. Economic and Political Weekly, 30(25), A64-A79.

Morton, J. F. (2007). The impact of climate change on smallholder and subsistence agriculture. In Proceedings of the National Academy of Sciences, 104(50), 19680-19685. Retrieved from http:// www.pnas.org/content/104/50/19680.abstract.

Myers, S. S., Zanobetti, A., Kloog, I., Huybers, P., Leakey, A. D. B., Bloom, A. J., ... Usui, Y. (2014). Increasing $\mathrm{CO}_{2}$ threatens human nutrition. Nature, 510(7503), 139-142. Retrieved from https://doi.org/10.1038/nature13179.

Nagayets, O. (2005). Small farms: Current status and key trends. In Information brief prepared for the "Future of Small Farms Research Workshop." Wye College, Kent.

Nakazibwe, P., \& Pelupessy, W. (2014). Towards a gendered agro-commodity approach. Journal of World-Systems Research, 20(2), 229-256. Retrieved from https://search.proquest.com/docview/ 1561499952 ?accountid $=10267$

Narayanan, S. (2014). Profits from participation in high value agriculture: Evidence of heterogeneous benefits in contract farming schemes in Southern India. Food Policy, 44, 142-157. https:// doi.org/10.1016/j.foodpol.2013.10.010.

Nkonya, E., Pender, J., Kaizzi, K., Kato, E., Mugarura, S., Ssali, H., \& Muwonge, J. (2008). Linkages between land management, land degradation, and poverty in sub-Saharan Africa: The case of Uganda. Washington D.C.

O’Brien, K., Leichenko, R., Kelkar, U., Venema, H., Aandahl, G., Tompkins, H., .. West, J. (2004). Mapping vulnerability to multiple stressors: Climate change and globalization in India. Global Environmental Change, 14(4), 303-313. http://doi.org/10.1016/j.gloenvcha.2004.01.001.

Ohkawa, K., \& Shinohara, M. (1979). Patterns of Japanese economic development: A quantitative appraisal. New Haven: Yale University Press. 
Otsuka, K., Chuma, H., \& Hayami, Y. (1992). Land and labor contracts in agrarian economies: Theories and facts. Journal of Economic Literature, 30(4), 1965-2018. Retrieved from http:// www.jstor.org/stable/2727971.

Otsuka, K., Liu, Y., \& Yamauchi, F. (2013). Factor Endowments, Wage Growth, and Changing Food Self-Sufficiency: Evidence from Country-Level Panel Data. American Journal of Agricultural Economics, 95(5), 1252-1258. Retrieved from https://doi.org/10.1093/ajae/aat028.

Otsuka, K., Liu, Y., \& Yamauchi, F. (2016). The future of small farms in Asia. Development Policy Review, 34(3), 441-461. https://doi.org/10.1111/dpr.12159.

Paerl, H. W., \& Huisman, J. (2009). Climate change: A catalyst for global expansion of harmful cyanobacterial blooms. Environmental Microbiology Reports, 1(1), 27-37. https://doi.org/10. $1111 /$ j.1758-2229.2008.00004.x.

Paterson, R. R. M., \& Lima, N. (2010). How will climate change affect mycotoxins in food? Food Research International, 43(7), 1902-1914. http://doi.org/10.1016/j.foodres.2009.07.010.

Perez, C., Jones, E. M., Kristjanson, P., Cramer, L., Thornton, P. K., Förch, W., \& Barahona, C. (2015). How resilient are farming households and communities to a changing climate in Africa? A gender-based perspective. Global Environmental Change, 34, 95-107. http://doi.org/10.1016/ j.gloenvcha.2015.06.003.

Pingali, P. (2007). Agricultural growth and economic development: A view through the globalization lens. Agricultural Economics, 37, 1-12. https://doi.org/10.1111/j.1574-0862.2007.00231.x.

Pingali, P. (2010). Agriculture renaissance: Making "agriculture for development" work in the 21st century (Chap. 74). In P. Pingali \& R. Evenson (Eds.), Handbook of agricultural economics, (Vol. 4, pp. 3867-3894). Elsevier. https://doi.org/10.1016/S1574-0072(09)04074-2.

Pingali, P. (2012). Green revolution: Impacts, limits, and the path ahead. Proceedings of the National Academy of Sciences, 109(31), 12302-12308. https://doi.org/10.1073/pnas.0912953109.

Pingali, P. (2015). Agricultural policy and nutrition outcomes-Getting beyond the preoccupation with staple grains. Food Security, 7(3), 583-591. https://doi.org/10.1007/s12571-015-0461-x.

Pingali, P. (2016). The hunger metric mirage: There's been less progress on hunger reduction than it appears. Proceedings of the National Academy of Sciences of the United States of America, $113(18)$.

Pingali, P., \& Khwaja, Y. (2004). Globalisation of Indian diets and the transformation of food supply systems. (ESA Working Paper No. 04-05). Rome, Italy.

Pingali, P., Khwaja, Y., \& Madelon, M. (2005). Commercializing small farms: Reducing transaction Cost. (ESA Working Paper No, 05-08).

Pingali, P., Khwaja, Y., \& Madelon, M. (2007). The role of the public and private sectors in commercializing small farms and reducing transaction costs. In J. F. M. Swinnen (Ed.), Global supply chains, standards and the poor (pp. 260-267). Oxford, UK: CABI International.

Pingali, P., Ricketts, K., \& Sahn, D. E. (2015). The fight against hunger and malnutrition: The role of food, agriculture, and targeted policies. In D. E. Sahn (Ed.), Agriculture for nutrition. Oxford, UK: Oxford University Press.

Pingali, P., \& Rosegrant, M. W. (1995). Agricultural commercialization and diversification: Processes and policies. Food Policy, 20(3), 171-185. https://doi.org/10.1016/0306-9192(95)00012-4.

Pingali, P., Schneider, K., \& Zurek, M. (2014). Poverty, agriculture and the environment: The case of sub-Saharan Africa. In J. von Braun \& F. W. Gatzweiler (Eds.), Marginality: Addressing the nexus of poverty, exclusion and ecology (pp. 151-168). Dordrecht Heidelberg New York London: Springer.

Pingali, P., Witwer, M., \& Abraham, M. (2016). Getting to zero hunger: Learnin from the MDGs for the SDGs. In P. D. Y. Lalaguna, C. M. D. Barrado, \& C. R. F. Liesa (Eds.), International society and sustainable development goals (pp. 175-202). Pamplona, Spain: Thomson Reuters Aranzadi.

Poulton, C., Dorward, A., \& Kydd, J. (2010). The future of small farms: New directions for services, institutions, and intermediation. World Development, 38(10), 1413-1428. https://doi.org/10.1016/ j.worlddev.2009.06.009. 
Pretty, J., Toulmin, C., \& Williams, S. (2011). Sustainable intensification in African agriculture. International Journal of Agricultural Sustainability, 9(1), 5-24. https://doi.org/10.3763/ ijas.2010.0583.

Quisumbing, A. R., \& Pandolfelli, L. (2010). Promising approaches to address the needs of poor female farmers: Resources, constraints, and interventions. World Development, 38(4), 581-592. https://doi.org/10.1016/j.worlddev.2009.10.006.

Quisumbing, A. R., Rubin, D., Manfre, C., Waithanji, E., van den Bold, M., Olney, D., ... Meinzendick, R. (2015). Gender, assets, and market-oriented agriculture: Learning from high-value crop and livestock projects in Africa and Asia. Agriculture and Human Values, 32(4), 705-725. https:// doi.org/10.1007/s10460-015-9587-x.

Ramaswami, B., Birthal, P. S., \& Joshi, P. K. (2009). Grower heterogeneity and the gains from contract farming: The case of Indian poultry. Indian Growth and Development Review, 2(1), 56-74. https://doi.org/10.1108/17538250910953462.

Rapsomanikis, G. (2015). The economic lives of smallholder farmers- An analysis based on household data from nine countries. Rome: Italy.

Ravallion, M., \& Chen, S. (2007). China's (uneven) progress against poverty. Journal of Development Economics, 82(1), 1-42. http://doi.org/10.1016/j.jdeveco.2005.07.003.

Reardon, T., Barrett, C. B., Berdegué, J. A., \& Swinnen, J. F. M. (2009). Agrifood industry transformation and small farmers in developing countries. World Development, 37(11), 1717-1727. https://doi.org/10.1016/j.worlddev.2008.08.023.

Reardon, T., \& Berdegué, J. A. (2002). The rapid rise of supermarkets in Latin America: Challenges and opportunities for development. Development Policy Review, 20(4), 371-388.

Reardon, T., \& Minten, B. (2011). Surprised by supermarkets: Diffusion of modern food retail in India. Journal of Agribusiness in Developing and Emerging Economies, 1(2), 134-161. https:// doi.org/10.1108/20440831111167155.

Reardon, T., \& Timmer, P. C. (2007). Transformation of markets for agricultural output in developing countries since 1950: How has thinking changed? (Chap. 55) In Handbook of agricultural economics (Vol. 3, pp. 2807-2855). Elsevier. https://doi.org/10.1016/S1574-0072(06)03055-6.

Reardon, T., Timmer, P. C., Barrett, C. B., \& Berdegué, J. A. (2003). The rise of supermarkets in Africa, Asia, and Latin America. American Journal of Agricultural Economics, 85(5), 1140-1146.

RFST. (2005). Impact of WTO on Women in Agriculture. New Delhi.

Rojas-Downing, M. M., Nejadhashemi, A. P., Harrigan, T., \& Woznicki, S. A. (2017). Climate change and livestock: Impacts, adaptation, and mitigation. Climate Risk Management, Forthcomin. http://doi.org/10.1016/j.crm.2017.02.001.

Rubin, D., \& Manfre, C. (2014). Promoting gender-equitable agricultural value chains: Issues, opportunities, and next steps. In A. R. Quisumbing, R. Meinzen-Dick, T. Raney, A. Croppenstedt, J. A. Behrman, \& A. Peterman (Eds.), Gender in agriculture and food security: Closing the knowledge gap. New York: Springer and FAO.

Schaffner, David, J., Schroder, W. R., \& Earle, M. D. (1998). Food marketing: An international perspective. Boston, MA: WCB McGraw-Hill.

Schipmann, C., \& Qaim, M. (2010). Spillovers from modern supply chains to traditional markets: Product innovation and adoption by smallholders. Agricultural Economics, 41(3-4), 361-371. https://doi.org/10.1111/j.1574-0862.2010.00438.x.

Sen, A. K. (1962). An aspect of Indian agriculture. The Economic Weekly, 14(46), 243-46.

Sen, A. K. (1966). Peasants and Dualism with or without Surplus Labor. Journal of Political Economy, 74, 425-450.

Sen, A. K. (2000). Social exclusion: Concept, application, and scrutiny (Social Development Paper No. 1). Bangkok.

Sheahan, M., \& Barrett, C. B. (2014). Understanding the agricultural input landscape in SubSaharan Africa recent plot, household, and community-level evidence (Policy Research Working Paper No. 7014).

Smith, P., Martino, D., Cai, Z., Gwary, D., Janzen, H., Kumar, P., ... Towprayoon, S. (2007). Agriculture. In B. Metz, O. R. Davidson, P. R. Bosch, R. Dave, \& L. A. Meyer (Eds.), Climate 
change 2007: Mitigation. Contribution of working group III to the fourth assessment report of the intergovernmental panel on climate change. Cambridge University Press, Cambridge.

Srivastava, R. (1989). Interlinked modes of exploitation in Indian agriculture during transition: A case study. The Journal of Peasant Studies, 16(4), 493-522. https://doi.org/10.1080/ 03066158908438404.

Swinnen, J. F. M., \& Maertens, M. (2007). Globalization, privatization, and vertical coordination in food value chains in developing and transition countries. Agricultural Economics, 37, 89-102. https://doi.org/10.1111/j.1574-0862.2007.00237.x.

Swinnen, J., \& Squicciarini, P. (2012). Mixed messages on prices and food security. Science, 335(6067), 405-406. https://doi.org/10.1126/science.1210806.

Thirtle, C., Lin, L., \& Piesse, J. (2003). The impact of research-led agricultural productivity growth on poverty reduction in Africa, Asia and Latin America. World Development, 31(12), 1959-1975. http://doi.org/10.1016/j.worlddev.2003.07.001.

Thorat, S. (2009). Economic exclusion and poverty linkages: A reflection on concept, consequences, and remedies in an Asian context. In J. von Braun, R. V. Hill, \& R. Pandya-Lorch (Eds.), The poorest and hungry assessments, analyses, and actions. Washington D.C: International Food Policy Research Institute.

Thornton, P. K., Kruska, R. L., Henninger, N., Kristjanson, P. M., Reid, R. S., Atieno, F., .. Ndegwa, T. (2002). Mapping poverty and livestock in the developing world. Nairobi, Kenya.

Timmer, P. C. (1988). The agricultural transformation (Chap. 8). In Handbook of development economics (Vol. 1, pp. 275-331). http://doi.org/10.1016/S1573-4471(88)01011-3.

Timmer, P. C., \& Akkus, S. (2008). The structural transformation as a pathway out of poverty: Analytics, empirics and politics (Working Paper No. 150). Washington D.C.

Trebbin, A., \& Franz, M. (2010). Exclusivity of private governance structures in agrofood networks: Bayer and the food retailing and processing sector in India. Environment and Planning, 42, 2043-2057.

Tubiello, F. N., Salvatore, M., Rossi, S., Ferrara, A., Fitton, N., \& Smith, P. (2013). The FAOSTAT database of greenhouse gas emissions from agriculture. Environmental Research Letters, 8(1), 15009. Retrieved from http://stacks.iop.org/1748-9326/8/i=1/a=015009.

Tzannatos, Z. (1999). Women and labor market changes in the global economy: Growth helps, inequalities hurt and public policy matters. World Development, 27(3), 551-569. http://doi.org/ 10.1016/S0305-750X(98)00156-9.

UNDP. (2009). Climate change in the African drylands: options and opportunities for adaptation and mitigation. New York.

United Nations. (2015). Transforming our world: The 2030 agenda for sustainable development. Resolution adopted by the General Assembly on 25 September 2015 (A/RES/70/1). New York: United Nations General Assembly.

von Braun, J., \& Kennedy, E. (1994). Agricultural Commercialization, economic development and nutrient. Baltimore: Maryland, USA: Johns Hopkins University Press.

Webb, P., \& Block, S. (2012). Support for agriculture during economic transformation: Impacts on poverty and undernutrition. Proceedings of the National Academy of Sciences, 109(31), 1230912314. Retrieved from http://www.pnas.org/content/109/31/12309.abstract.

Mathew Abraham is the Assistant Director of the Tata-Cornell Institute for Agriculture and Nutrition at the Charles H. Dyson School of Applied Economics and Management at Cornell University. He has a Ph.D. from the Department of International Economics and Management, Copenhagen Business School, Denmark. He has over a decade of experience working in agriculture and food security. His research interests are in agricultural markets, collective action in agriculture, food security in developing countries, institutional innovation in rural development, and social entrepreneurship. 
Open Access This chapter is licensed under the terms of the Creative Commons Attribution 4.0 International License (http://creativecommons.org/licenses/by/4.0/), which permits use, sharing, adaptation, distribution and reproduction in any medium or format, as long as you give appropriate credit to the original author(s) and the source, provide a link to the Creative Commons license and indicate if changes were made.

The images or other third party material in this chapter are included in the chapter's Creative Commons license, unless indicated otherwise in a credit line to the material. If material is not included in the chapter's Creative Commons license and your intended use is not permitted by statutory regulation or exceeds the permitted use, you will need to obtain permission directly from the copyright holder.

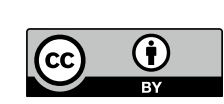

